NBER WORKING PAPER SERIES

\title{
CRISIS RESOLUTION AND BANK LIQUIDITY
}

\author{
Viral V. Acharya \\ Hyun Song Shin \\ Tanju Yorulmazer \\ Working Paper 15567 \\ http://www.nber.org/papers/w15567
NATIONAL BUREAU OF ECONOMIC RESEARCH
1050 Massachusetts Avenue \\ Cambridge, MA 02138 \\ December 2009
}

This paper was circulated earlier under the title "Fire Sales, Foreign Entry and Bank Liquidity." We are grateful to Franklin Allen, Heitor Almeida, Giacinta Cestone (discussant), Douglas Gale, Alan Morrison (discussant), Leonard Nakamura, Raghuram Rajan, Tano Santos (discussant), Ellis Tallman and Matthew Willison for their suggestions, to seminar participants at London Business School, Bank of England, University of Durham, International Conference on Asset Prices and Firm Policies in June 2006 in Verona, Workshop on Banking, Risk and Regulation hosted by BCBS and FDIC in May 2007, the UniCredit Group Conference on Banking in Finance in December 2007 in Naples and the American Finance Association Meetings in January 2009 for their comments, and to Yili Zhang for excellent research assistance. All errors remain our own. The views expressed here are those of the authors and do not necessarily represent the views of the Federal Reserve Bank of New York, the Federal Reserve System, or the National Bureau of Economic Research.

NBER working papers are circulated for discussion and comment purposes. They have not been peerreviewed or been subject to the review by the NBER Board of Directors that accompanies official NBER publications.

(C) 2009 by Viral V. Acharya, Hyun Song Shin, and Tanju Yorulmazer. All rights reserved. Short sections of text, not to exceed two paragraphs, may be quoted without explicit permission provided that full credit, including $(\mathrm{C}$ notice, is given to the source. 
Crisis Resolution and Bank Liquidity

Viral V. Acharya, Hyun Song Shin, and Tanju Yorulmazer

NBER Working Paper No. 15567

December 2009

JEL No. D62,E58,G21,G28,G38

\begin{abstract}
$\underline{\text { ABSTRACT }}$
What is the effect of nancial crises and their resolution on banks' choice of liquid asset holdings? When risky assets have limited pledgeability and banks have relative expertise in employing risky assets, the market for these assets clears only at fire-sale prices following a large number of bank failures. The gains from acquiring assets at fire-sale prices make it attractive for banks to hold liquid assets. We show that the resulting choice of bank liquidity is counter-cyclical, inefficiently low during economic booms but excessively high during crises, and present and discuss evidence consistent with these predictions. Since inefficient users may enter asset markets when prices fall sufficiently, interventions to resolve banking crises may be desirable ex post. However, policies aimed at resolving crises affect ex-ante bank liquidity in subtle ways: while liquidity support to failed banks or unconditional support to surviving banks in acquiring failed banks give banks incentives to hold less liquidity, support to surviving banks that is conditional on their liquid asset holdings creates incentives for banks to hold more liquidity.
\end{abstract}

Viral V. Acharya

Stern School of Business

New York University

44 West 4th Street, Suite 9-84

New York, NY 10012

and NBER

vacharya@london.edu

Hyun Song Shin

Bendheim Center for Finance

Princeton University

26 Prospect Avenue

Princeton, NJ 08540-5296

hsshin@princeton.edu
Tanju Yorulmazer

Federal Reserve Bank of New York

33 Liberty Street

New York, NY 10045

tanju.yorulmazer@ny.frb.org 


\section{Introduction}

A central difficulty during banking crises is one of finding ready buyers of distressed assets. If a bank needs to restructure its balance sheet during a crisis or be sold as a going concern, the potential buyers are generally other banks, but they may have also been severely affected and thus be financially constrained and unable to purchase the bank or its assets. This theme is a familiar one from corporate finance (see Williamson, 1988, and Shleifer and Vishny, 1992), but leads to especially severe problems in a banking crisis given the relative opacity of bank balance sheets and the high sensitivity of banking assets to macroeconomic shocks. Allen and Gale (1998) have shown in the context of the Diamond and Dybvig (1983) setup that asset prices can fall below their fundamental value in adverse states of the world, giving rise to "cash-in-the-market" (or fire-sale) pricing. Surviving banks that do have enough liquidity during such states stand to make windfall profits from purchasing assets at fire-sale prices. Even if crises arrive infrequently, the potential gains from acquisitions at fire sales could be large. This gives banks incentives to hold liquid assets so that in the event that they survive the crisis, they will have resources to take advantage of fire sales. ${ }^{1}$

Our objective in this paper is to present a model of banks' choice of ex-ante liquidity that is driven by such strategic considerations. We examine the portfolio choice of banks maximizing their profits in the presence of fire sales that are endogenously derived in an equilibrium setup of the banking industry. While risky assets are attractive to banks given their limited liability, risky assets' cash flows are illiquid and have limited pledgeability. This limited pledgeability of risky cash flows, coupled with the potential for future acquisitions at fire-sale prices, induces banks to hold liquid assets in their portfolios. In essence, bank portfolio choice acquires an inter-temporal dimension even in an otherwise myopic set-up. ${ }^{2}$

\footnotetext{
${ }^{1}$ See Allen and Carletti (2008) for a recent overview of the issues. Cleveland and Thomas in their book Citibank provide a memorable account of how National City Bank, that eventually became Citibank, grew from a small treasury unit into one of the biggest commercial banks under its president Stillman, who anticipated the 1893 and 1907 crises and built up liquidity and capital before the crises to benefit from the difficulties of its competitors. We describe this case in greater detail in Section 5 .

${ }^{2}$ Indeed, we show that this dimension arises in our model purely due to the benefit from holding liquid assets while purchasing failed banks, and not from the more traditional precautionary desire for holding liquidity to avoid default. Brown and Dinc (2009, Table 1) shows that bank sales are quite common during crises. In particular, out of 210 failed banks in 21 countries (10 largest failures in each) during 1994 to 2000, they have data on the resolution for 72 private bank failures: 34 are taken over by the government, 6 have licenses revoked, and 32 are sold to other financial institutions (out of which 3 sales are government-assisted).
} 
We show that banks' equilibrium holding of liquid assets is decreasing in the pledgeability of risky cash flows. One possible interpretation of this result is that bank liquidity is countercyclical, that is, decreasing in the health of the economy. During economic upturns, expected profits from risky assets are high and so is their pledgeability. ${ }^{3}$ An important implication is that adverse asset-side shocks that follow good times result in deeper fire-sale discounts since bank balance-sheets feature low liquidity in such times, whereby conditional on unexpected adverse shocks, there is lower aggregate liquidity to clear market for assets. Although we do not endogenize the variability of the haircut in this paper, we do acknowledge the importance of this key issue for understanding the financial crises in a market-based financial system.

We also compare the privately optimal levels of bank liquidity with benchmark levels that maximize the overall banking sector output. The pledgeability of risky cash flows turns out to be the critical determinant of whether banks hold too little or too high liquidity relative to the socially optimal level. When pledgeability is high, banks hold less liquidity than is socially optimal due to the preference for risky exposures induced by limited liability; otherwise, banks may hold even more liquidity than is socially optimal in order to capitalize on fire sales. This latter result may seem surprising but is explained simply: fire sales result in transfers of value amongst banks but do not lead to any aggregate welfare gains or costs, and thus, liquidity hoarded to capitalize on fire sales may in some cases be excessive from the standpoint of maximizing banking sector output.

We present descriptive evidence on the asset liquidity of banks across countries. This evidence suggests that banks' choice of liquidity seems to vary along dimensions that would be correlated with difficulty in raising external finance and the severity of financial distress. We show that banks hold more liquid assets in those countries that have (i) less developed accounting standards; (ii) lower total market capitalization relative to GDP; and, (iii) lower liquidity in stock markets. We also discuss empirical evidence consistent with our model's implication that bank liquidity would be counter-cyclical.

We revert to the theoretical model to analyze the effect of entry by outsiders (users

\footnotetext{
${ }^{3}$ Shin (2008) documents based on data from Bloomberg, that the typical haircuts on treasuries, corporate bonds, AAA asset-backed securities, AAA residential mortgage-backed securities and AAA jumbo prime mortgages are respectively, less than $0.5 \%, 5 \%, 3 \%, 2 \%$ and 5\%, whereas, in March 2008, these haircuts respectively rose to between $0.25 \%$ and $3 \%, 10 \%, 15 \%, 20 \%$ and $30 \%$ (also see Box 1.5 from Chapter 1, Page 42 of IMF (2008)). Brunnermeier and Pedersen (2008) also discuss the widening of haircuts in stress times. Gorton and Metrick (2009) show that during 2007-08, the repo haircuts on a variety of assets rose on average from zero in early 2007 to nearly 50 percent in late 2008 .
} 
of banking assets outside the banking sector) for acquisition of assets during crises. Since outsiders may lack expertise relative to surviving banks, they enter only when fire sales are sufficiently deep. On the one hand, this has the effect of increasing the aggregate pool of liquidity for resolving bank failures and stabilizing prices of bank assets; on the other hand, entry of outsiders reduces the ability of surviving insiders to acquire assets, resulting in an allocation inefficiency. Thus, it may be attractive for central banks and policy makers to intervene ex post to limit this misallocation.

How do policy interventions aimed at resolving bank failures affect the ex-ante choice of bank liquidity? We answer this question by focusing on various forms of resolution or lenderof-last-resort policies of central banks. In particular, we consider three different policies: (i) liquidity support to failed banks (or, in other words, bailouts); (ii) unconditional liquidity support to surviving banks; and (iii) liquidity support to surviving banks conditional on the level of liquid assets in their portfolios. We show that the first two policies decrease banks' incentives to hold liquidity, as the first policy limits fire-sale opportunities and the second policy guarantees the liquidity desired by surviving banks for acquisitions at fire-sale prices. In contrast, the third policy increases banks' incentives to hold liquidity.

Hence, the effect of resolution policies on ex-ante bank liquidity is rather subtle. Depending on whether banks are hoarding too much liquidity or taking excessive risks compared to the socially optimum level, regulators and central banks can employ different resolution policies - lend unconditionally to create incentives to unlock inefficiently high levels of liquid asset holdings, or create incentives for holding even more liquidity by employing the conditional liquidity provision policy.

The global financial crisis of 2007-2009 offers a live laboratory for many of the themes explored in this paper. In the process of resolving weak and failing banks, banks with apparently stronger balance sheets have been selected as the potential acquirers of weak banks. In the United States, the role of J.P. Morgan Chase in acquiring Bear Stearns in March 2008 first captured headlines. But the theme played out again with the takeover of Merrill Lynch by Bank of America in September of 2008 and of Wachovia by Wells Fargo in October 2008. In these instances, stronger banks have placed themselves in the position to acquire rivals that have been weakened by the crisis. ${ }^{4}$ As Bank of America's troubled takeover of Merrill

\footnotetext{
${ }^{4}$ Although stronger capital positions (and hence lower leverage) are an important consideration in positioning oneself in anticipation of crises, our focus here is on the composition of the asset side of the balance sheet between risky and safe assets. Both capital and liquidity in general will be important, but our purpose
} 
Lynch has shown, such acquisitions are not without risk. ${ }^{5}$ However, crises do seem to present a unique opportunity for banks to boost their relative standing in the industry.

The role of cash holdings in bank portfolios have also come to the fore during the crisis. Figure 1 shows the holding of cash by U.S. commercial banks as a proportion of total assets, as shown in the H8 database of the Federal Reserve. As recently as the early 1980s, cash holdings (vault cash plus reserves at the Fed) were approximately 10 percent of total assets. However, that proportion got eroded gradually, until it dipped below 3 percent in recent years. Since the beginning of the most severe phase of the financial crisis (in particular beginning in September 2008), the cash holdings have shot up dramatically.

Figure 2 is a weekly series that shows the precise timing of the surge in cash holdings. We see the striking break in the trend in the second week of September of 2008, i.e. after the Lehman Brothers bankruptcy. Even though the first wave of the subprime crisis happened in the summer of the previous year (August 2007), the cash holding of U.S. commercial banks continued to fall right up to the Lehman Brothers failure. Although many other factors may have been at play in explaining these cash holdings (such as the Fed's aggressive liquidity injections through growth of reserves, as well as the disbursement of TARP funding), our paper points to one possible contributory motive - namely, the preservation of a liquid balance sheet that can be used to acquire weakened rivals. In any case, this evidence of a substantial rise in cash holdings throws up the choice of liquidity as an important issue that deserves further investigation.

The erosion of cash holdings in the run-up to the crisis and the subsequent rapid build-up of cash also highlight the welfare trade-offs discussed in our paper. Our central theme is that banks can hold too little cash during booms, and perhaps too much during busts, relative to the first-best levels. Figures 1 and 2 suggest that it is worth asking the question whether banks held too little cash before September 2008, and whether they have been holding too much since then, at the expense of lending to a credit-starved economy. Our theoretical framework provides some help in guiding the analysis.

Section 2 presents the related literature. Sections 3 and 4 set up the benchmark model without outsiders and characterize the effect of fire sales on bank liquidity. Section 5 provides

in this paper is to highlight the role of the latter. However, this emphasis on liquidity should not be taken as implying that capital is unimportant.

${ }^{5}$ The takeover of the U.K. bank HBOS by its domestic rival Lloyds has similarly been disastrous. 
descriptive empirical evidence. Section 6 considers entry by liquidity-endowed outsiders and analyzes the effect of resolution policies on banks' choice of liquidity. Section 7 concludes. All proofs not in the main text are in the Appendix.

\section{Related literature}

The relationship between liquidity and asset prices has been used in the literature to examine a number of issues such as financial market runs (Bernardo and Welch, 2004, and Morris and Shin, 2004), strategic lending and trading (Donaldson, 1992, Brunnermeier and Pedersen, 2005 and Acharya, Gromb and Yorulmazer, 2007), contagion through asset prices (Gorton and Huang, 2004, Schnabel and Shin, 2004, Allen and Gale, 2005, Cifuentes, Ferrucci and Shin, 2005, Diamond and Rajan, 2005, and Allen and Carletti, 2006), and optimal resolution of bank failures (Acharya and Yorulmazer, 2007, 2008). Most of the literature cited above treats the level of liquidity (of banks) as exogenous, excepting a few papers that are discussed below.

Banks can hold liquidity for various reasons such as the "precautionary" motive of insuring against their depositors' uncertain liquidity needs and the "strategic" motive of being able to take advantage of profitable options when they arise. We abstract from the precautionary motive which finds a strong parallel in the corporate-finance literature on firms' propensity to save in the form of cash holdings (see, for example, Acharya, Almeida and Campello, 2007 , and the literature cited therein). Instead, we focus exclusively on the strategic one, the profitable option being the opportunity to acquire other banks' assets cheap. On this score, our paper is more in the spirit of recent papers by Allen and Gale (2004a,b) and Gorton and Huang (2004) who also investigate how liquidity is endogenously determined. ${ }^{6}$

Our paper differs from these recent papers along the following dimensions. Rather than modeling bank runs as an endogenous choice of depositors, we assume that deposits are hard contracts and thus bank failures occur whenever asset shocks are sufficiently adverse. The resulting simplicity of the model allows us to derive interesting comparative static results as

\footnotetext{
${ }^{6}$ Allen and Gale (2004b), for example, build a model where runs by depositors result in fire-sale liquidation of banking assets. Banks endogenously choose the level of the liquid asset, which they use to purchase banking assets. Since on average the liquid asset has a lower return than the risky asset, banks have to be compensated for holding liquid assets, which is possible in equilibrium if they can purchase the risky asset at a discount in some states of the world, leading to cash-in-the-market pricing.
} 
to how bank liquidity is affected by the ease of external finance and thereby the business cycle. These results are made possible by the fact that our model does not rule out external financing against risky cash flows altogether (as in the related papers cited above), but instead allows for a limited pledgeability of risky cash flows arising from moral hazard considerations, as in Holmstrom and Tirole (1998). Under this limited pledgeability assumption, we also address welfare issues such as whether the private level of bank liquidity is the efficient one and what is the effect of entry of outside capital and resolution policies on bank liquidity. ${ }^{7}$

We acknowledge that since liquid assets usually have lower returns than illiquid assets, banks may rationally choose to rely on liquidity from an interbank market or a lender of last resort (LOLR). Bhattacharya and Gale (1987) build a model of the interbank market where individual banks that are subject to liquidity shocks coinsure each other against these shocks through a borrowing-lending mechanism. However, in their model, the composition of liquid and illiquid assets in each bank's portfolio and the liquidity shocks are private information. Hence, banks have an incentive to under-invest in liquid assets and free-ride on the common pool of liquidity in the interbank market. Repullo (2005) shows that the existence of LOLR results in banks holding a lower level of the liquid asset as they rely on the LOLR for liquidity. While we do not consider inter-bank lending in this paper, we do analyze in Section 6 the implications of different resolution policies on bank liquidity.

In a recent paper, Bolton et al. (2008) build a model where asset illiquidity arises due to asymmetric information about the asset value. As in our model, for liquidity needs, financial intermediaries can rely on the liquid assets in their portfolio (inside liquidity) or can sell assets (outside liquidity), in which case there is a lemons problem that can potentially lead to a "delayed" sale of assets and at fire-sale prices. While asymmetric information and complexity of assets is the main friction in their paper, in our model even non-complex assets may suffer from fire-sale discounts if shocks to banks are sufficiently severe, given the moral hazard affecting pledgeability of risky assets.

In another recent paper, Diamond and Rajan (2009) appeal to the risk-shifting incentives of troubled banks to generate delay in the sale of assets. Such delay substantially raises the anticipated gains from future fire sales, raising the expected returns to holding cash across the

\footnotetext{
${ }^{7}$ It should also be noted that since moral hazard arises only because insiders have expertise with regard to risky assets, our modeling assumptions are consistent with outside capital being a second-best user of banking assets. This explains why outside capital does not enter during crises until discounts are steep so that a high shadow value of capital may co-exist with ready funds (waiting) outside the system at the onset of crises.
} 
financial system and giving rise to a credit freeze. Both Bolton et al. (2008) and Diamond and Rajan (2009) represent models wherein once an adverse state of the world arises, decisions of individual banks affect when assets get sold - right away or with delay. In contrast, our paper is more in the spirit of Allen and Gale (1994, 1998) and Gorton and Huang (2004) in that once the adverse state arises, there is either a depositor run or prompt regulatory intervention that leads to immediate (fire) sale of assets.

\section{Benchmark model}

We start with an informal description of the building blocks of the model and its key assumptions. We consider a setting with a large number of banks. Banks solve a portfolio choice problem: they maximize their profits by choosing how much to invest in risky assets, which are assumed to have diminishing returns to scale, and how much to park in the safe asset as liquid reserves. This portfolio choice problem acquires an inter-temporal dimension since there is limited pledgeability of risky cash flows and therefore a relative benefit from holding liquidity in states where banks can profit from asset purchases at fire-sale discounts. Specifically, while banks have a preference for the risky asset due to its "option" value in the traditional risk-shifting sense (Jensen and Meckling, 1976), there is a counteracting preference for the safe asset due to its greater liquidity relative to the risky asset.

Banks' choice of liquidity trades off the expected returns from the two kinds of assets taking account of the option value of the risky asset and the need for inter-temporal transfers of liquidity. The benchmark socially optimal level of liquid asset holdings in banks' portfolio maximizes the value of the banking sector as a whole, that is, the sum of the values of banks (rather than just banks' profits). In the first part of our analysis, we assume that when banks fail, the only potential purchasers are other banks. We also assume that deposits are insured by the regulator and that there is no cost of providing insurance to depositors, in which case the assumption of insured deposits does not play a key role in the determination of liquidity choices of banks. We introduce entry by outsiders in Section 6 and analyze the effect of resolution policies on banks' choice of liquidity.

The time line of the model is outlined in Figure 3, where time is indexed by $t \in\{0,1,2\}$. In the benchmark model, there are banks, bank owners, depositors and a regulator, who provides deposit insurance. 
There is a continuum of banks with measure one and each bank has access to its own depositor base, which consists of a continuum of depositors of measure one. Bank owners and depositors are risk-neutral, and the universal discount rate is zero.

Depositors receive a unit endowment at $t=0$ and have access to a reservation investment opportunity that gives them a utility of one per unit of investment. At date $t=0$, depositors choose to invest their good in this reservation opportunity or in their bank. Deposits take the form of a simple debt contract with maturity of one period and the promised deposit rate is not contingent on bank's investment decisions or its realized returns. Depositors are assumed to be insured.

Banks collect one unit of deposits from depositors and make investments to maximize expected profits. $^{8}$ In particular, banks choose a portfolio by investing $l$ units in a safe asset and the remaining $(1-l)$ units in a risky asset, which is to be thought of as a portfolio of loans to firms in the corporate sector.

The payoff of the bank from its loan is realized at $t=2$, where the return, denoted by $\widetilde{R}$, is a random variable:

$$
\widetilde{R}=\left\{\begin{array}{c}
R>1 \quad \text { with prob. } \alpha \\
r<1 \quad \text { with prob. } 1-\alpha
\end{array} .\right.
$$

$R$ can be viewed as the notional value of the loan. The realization of $\widetilde{R}$ is independent across banks, so that by law of large numbers, precisely a proportion $\alpha$ of the banks have the high return. However, there is aggregate uncertainty in that $\alpha$ is itself random. Hence, there is uncertainty over the proportion of banks that receive the positive payoff.

The risky technology $\widetilde{R}$ has diminishing returns to scale when the return is high, that is, the return $R$ is decreasing in $(1-l)$. In order to get a closed-form solution, we use a setup similar to Holmstrom and Tirole (2001) and let

$$
R(l)=b-\frac{(1-l)}{2} .
$$

Hence, $R$ takes values between $\left(b-\frac{1}{2}\right)$ and $b$, and $\frac{d R}{d l}=\frac{1}{2}>0$. We assume that $r$ is independent of $l$, which simplifies the analysis.

\footnotetext{
${ }^{8}$ We implicitly assume that each bank has a depositor base of 1 unit and, for simplicity, we refrain from modelling competition among banks for deposits. One reason why banks may have such captive depositors is the presence of switching costs that has strong empirical support in the literature as documented by Kiser (2002) for the U.S., Kim, Kliger and Vale (2003) for Norway, and Gondat-Larralde and Nier (2006) for the U.K.
} 
At the intermediate date $t=1$, the outcome of the investments in the risky asset becomes public information, though banks can collect these returns fully only at $t=2$. This setup of interim information revelation is based on the model of Allen and Gale (1998) and is motivated by the observation that bank runs are generally coincident with a poor performance of underlying assets (Gorton, 1988, and Calomiris and Gorton, 1991).

The safe asset is completely liquid and pays one unit at any date for each unit invested. The risky asset is however not completely liquid due to a moral-hazard problem at the bank level. From date $t=1$ to date $t=2$, if the bank does not exert effort, then when the return is high, it cannot generate $R$ but only $(R-\bar{\Delta})$ and its owners enjoy a non-pecuniary benefit of $B \in(0, \bar{\Delta}) .{ }^{9}$ For the bank owners to exert effort, appropriate incentives have to be provided by giving bank owners a minimum share of the bank's profits. We denote this share as $\theta$. If $d$ is the promised payment to depositors, then the incentive-compatibility constraint is:

$$
\theta(R-d) \geqslant \theta(R-\bar{\Delta}-d)+B
$$

Under this constraint, bank owners need a minimum share of $\bar{\theta}=B / \bar{\Delta}$ to monitor loans properly. ${ }^{10}$ Therefore, the bank can raise in the capital market at date $t=1$ at most a fraction $\tau=(1-\bar{\theta})$ of its income at $t=2$ if it is required to exert effort to monitor loans. ${ }^{11}$ We assume that at $t=0$, the entire share of the bank profits belongs to the bank owners, and therefore, moral hazard is not a concern to start with, whereas it can become an issue at $t=1$ when the bank wants to pledge its future cash flows in the capital market.

Finally, we make technical assumptions (A1)-(A4) which are outlined in the Appendix. We refer to these at a few relevant points of our analysis.

Before we solve the model, note first that if a bank's return from the risky investment is high, then the bank operates until date $t=2$. If the return from the risky investment is low, then the bank is in default and its assets are put up for sale by the same regulator at $t=1$. We do not model the closure and liquidation process of the bank. A bank with the low return does not have enough funds to pay existing depositors since $d \geqslant 1$ and $r<1$. Since there is full deposit insurance, depositors do not have incentives to "run" at $t=1$, but bankers

\footnotetext{
${ }^{9}$ See Hart and Moore (1994) and Holmstrom and Tirole (1998) for models with similar incentivecompatibility constraints.

${ }^{10}$ Note that once the bank is left with a share that is less than $\bar{\theta}$, it might as well pledge the entire future return of $(R-\bar{\Delta}-d)$. For $\bar{\Delta}>\sqrt{B(R-d)}$, this is less than $(1-\bar{\theta})(R-d)$, the amount that can be pledged when the bank chooses the good project. Throughout, we assume that $\bar{\Delta}>\sqrt{B(R-d)}$.

${ }^{11}$ See Section 5.1 for a discussion of empirical support for the relevance of moral hazard in banking.
} 
may attempt to steal these funds (Calomiris and Kahn, 1991) or have adverse incentives to gamble for resurrection (Jensen and Meckling, 1976). If these agency problems at distressed banks are sufficiently severe, then it will be optimal for the regulator to liquidate the bank at $t=1$, rather than keep it open. We assume this to be the case.

When banks with the high return from the risky investment want to acquire failed banks' assets, they use the liquid asset in their portfolio and/or try to raise funds from the capital market against their future return. However, because of moral hazard, banks cannot fully pledge their future income, but only a fraction $\tau$ of it.

Depending on the returns, a proportion $k=(1-\alpha)$ of banks fail. Since banks are identical at $t=0$, we denote without loss of generality the possible states at $t=1$ with $k$.

\section{Analysis}

We now investigate the sale of failed banks' assets, the resulting asset prices and the ex-ante choice of bank liquidity.

\subsection{Asset sales and liquidation values}

To keep the analysis tractable and at the same time reasonable, we make the following assumptions:

(i) The regulator pools all failed banks' assets and auctions them to the surviving banks.

(ii) Denoting the surviving banks in state $k$ as $i \in[0,1-k]$, each surviving bank submits a schedule $y_{i}(p)$ for the amount of assets they are willing to purchase as a function of the price $p$ at which a unit of the banking asset (inclusive of associated deposits) is being auctioned.

(iii) The regulator determines the auction price $p$ so as to maximize the output of the banking sector subject to the natural constraint that portions allocated to surviving banks add up at most to the number of failed banks, that is,

$$
\int_{0}^{1-k} y_{i}(p) d i \leq k
$$

(iv) We focus on the symmetric outcome where all surviving banks submit the same schedule, that is, $y_{i}(p)=y(p)$ for all $i \in[0,1-k]$. 
First, we derive the demand schedule for surviving banks. Note that a surviving bank can generate a maximum return of $\bar{p}=r$ from the risky asset in the second period. Hence, the maximum price a surviving bank is willing to pay for a failed bank's asset is $\bar{p}$. Also, a surviving bank can generate $\tau[(1-l) R-d]$ units from the capital market at $t=1$. Hence, the resources available with a surviving bank for purchasing failed banks' assets equal

$$
L=l+\tau[(1-l) R-d]
$$

provided that the return from the risky asset is enough to pay existing depositors, that is, when $(1-l) R \geqslant d$. For $R=\left(b-\frac{1-l}{2}\right)$, this condition is met when $l \leqslant l_{\max }=\left[\sqrt{b^{2}-2}+(1-b)\right]$. We show later that under (A1) and (A2), banks never hold a level of liquidity $l$ greater than $l_{\text {max }}$ in equilibrium. Finally, (A2) also guarantees that the liquidity banks have for asset purchases increases as they hold more liquid asset, that is, $\frac{\partial L}{\partial l}>0$.

The expected profits of a surviving bank from the asset purchase equal $y(p)[\bar{p}-p]$. The surviving bank wishes to maximize these profits subject to the resource constraint $y(p) \cdot p \leq L$. Hence, for $p<\bar{p}$, surviving banks are willing to purchase the maximum amount of assets using their resources, and their demand schedule for assets is $y(p)=\frac{L}{p}$. For $p>\bar{p}$, the demand is $y(p)=0$, and for $p=\bar{p}$, banks are indifferent between values of $y(p)$ over the range $\left[0, \frac{L}{\bar{p}}\right]$. In words, as long as purchasing assets is profitable, a surviving bank wishes to use up all its resources to purchase failed banks' assets.

Next, we analyze how the regulator allocates failed banks' assets and the resulting price function. The regulator cannot set $p>\bar{p}$ since in this case $y(p)=0$. If $p \leqslant \bar{p}$, and the proportion of failed banks is sufficiently small, then the surviving banks have enough funds to pay the full price for all failed banks' assets. Specifically, for $k \leq \underline{k}$, where

$$
\underline{k}=\frac{L}{L+(1-l) \bar{p}}
$$

the regulator sets the price at $p^{*}(k)=\bar{p}$. At this price, surviving banks are indifferent between any quantity of assets purchased. Hence, we assume that the regulator allocates a share $y\left(p^{*}\right)=\frac{(1-l) k}{1-k}$ to each surviving bank.

For values of $k>\underline{k}$, surviving banks cannot pay the full price for all failed banks' assets and the regulator sets the price at

$$
p^{*}(k)=\frac{(1-k) L}{(1-l) k} .
$$


Note that, in this region, surviving banks use all available funds and the price falls as the number of failures increase. This effect is basically the cash-in-the-market pricing as in Allen and Gale $(1994,1998)$ and is also akin to the industry-equilibrium hypothesis of Shleifer and Vishny (1992). The resulting price function is formally stated in the following proposition and is illustrated in Figure 4.

Proposition 1 The price of failed banks' assets as a function of the proportion of failed banks is as follows:

$$
p^{*}(k)=\left\{\begin{array}{ccc}
\bar{p} & \text { for } & k \leqslant \underline{k} \\
\frac{(1-k) L}{(1-l) k} & \text { for } & k>\underline{k}
\end{array} .\right.
$$

From equation (5), one can see that as banks hold less of the liquid asset, $\underline{k}$ decreases, that is, the region over which the price is equal to the fundamental price $\bar{p}$ shrinks. In turn, from Proposition 1 and Figure 4, it follows that for all values of $k$, when banks hold less of the liquid asset, prices deviate more from the fundamental price, that is, $\left(\bar{p}-p^{*}(k)\right.$ ) (weakly) increases. This gives us the following Corollary.

Corollary 1 For all $k \in[0,1]$, as liquidity in banks' portfolio l decreases, price deviates more from the fundamental price $\bar{p}$, that is, $\left(\bar{p}-p^{*}(k)\right)$ (weakly) increases.

\subsection{Banks' choice of liquidity}

Consider a representative bank at $t=0$. Formally, the objective of each bank is to choose a portfolio of the safe and the risky asset, namely $(l, 1-l)$, that maximizes expected profits, which consists of profits from (i) their own investments taking account of the opportunity cost of holding liquid assets in their portfolio, and (ii) asset purchases when they survive.

Using the prices derived in Proposition 1, we can calculate profits for surviving banks from asset purchases. When only a small proportion of banks fail $(k \leq \underline{k})$, surviving banks pay the full price for the acquired assets and do not capture any surplus from the asset purchase. In this case, from an ex-post standpoint, banks carry excess liquidity in their portfolio and incur losses from forgone investment in the risky asset.

When the proportion of failed banks is high $(k>\underline{k})$, each surviving bank captures a 
surplus from asset purchase that equals

$$
y\left(p^{*}\right) \cdot\left(\bar{p}-p^{*}\right)=\left(\frac{(1-l) k}{1-k}\right) \bar{p}-L .
$$

In all cases, owners of failed banks have no continuation payoffs.

Given this analysis, each banks' problem is to choose $l$ that maximizes

$$
E(\pi(l))=E\left(\alpha\left[[l+(1-l) R(l)-d]+L\left(\frac{\bar{p}-p^{*}(k)}{p^{*}(k)}\right)\right]\right),
$$

where $p^{*}(k)$ is the market clearing price given in Proposition 1. The first order condition (FOC) for the maximization problem is given as:

$$
E\left[\alpha\left(\left[1-R+(1-l) \frac{d R}{d l}\right]+\left[1-\tau R+\tau(1-l) \frac{d R}{d l}\right]\left[\frac{\bar{p}-p^{*}(k)}{p^{*}(k)}\right]\right)\right]=0
$$

We define

$$
\phi \equiv \alpha\left[\frac{\bar{p}-p^{*}(k)}{p^{*}(k)}\right]
$$

as the expected benefit from asset purchase per unit of liquidity. See Figure 5 for an illustration of $\phi$ as a function of $k$. Note that $\phi$ is independent of $l$ when viewed from a price-taking bank's perspective, but in equilibrium, $p^{*}(k)$ depends on the aggregate liquidity in state $k$. Hence, banks' equilibrium choice of liquid asset holdings is given by a fixed point that is formally stated below and illustrated in Figure $6{ }^{12}$

Proposition 2 Banks' choice of liquidity $\widehat{l}$ that satisfies the FOC in (10) is given by

$$
\widehat{l}=\min \left\{1, \max \left\{0,1-b+\frac{E(\alpha)+E(\phi)}{E(\alpha)+\tau E(\phi)}\right\}\right\} .
$$

\footnotetext{
${ }^{12}$ Here, we focus on symmetric equilibrium. However, we need to stress the point that there exist equilibria where some (but not all) banks invest all their funds in the liquid asset whereas other banks invest some (or all) of their funds in the risky asset. The important point is that all equilibria share the same feature that in some states of the world where a sufficiently large proportion of banks fail, aggregate liquidity will be limited, asset prices will fall below their fundamental value, we will observe asset price volatility and cash-in-the-market pricing as in Allen and Gale (1994). This result is consistent with the findings of Allen and Gale (2004a) who show, using the framework of Diamond and Dybvig (1983), that the robust equilibrium is associated with cash-in-the-market pricing and asset-price volatility. Also, see Allen and Gale (2005) for a review of the literature that explores the relation between asset-price volatility and financial fragility when markets and contracts are incomplete.
} 
The unique aggregate equilibrium level of liquidity $l^{*}$ is the fixed-point of

$$
\widehat{l}\left(E(\alpha), \tau, E\left(\phi\left(\alpha, \tau, l^{*}\right)\right)\right)=l^{*},
$$

and we obtain $l^{*} \leq l_{\max }<1$.

Note that $\widehat{l}$ is a (weakly) declining function of aggregate liquidity $l$. The intuition for this is that if aggregate liquidity is low, then the deviation of prices from the fundamental value is high, creating a motive to hold liquidity to acquire failed banks at lower prices. Conversely, if aggregate liquidity is high, then the expected gain from asset purchases is low and the incentives of a bank to carry liquid buffers is low as well.

Several aspects of banks' private choice of liquidity $l^{*}$ deserve mention. First, under (A1), we have $b>2$ and banks never have an incentive to hold liquidity if pledgeability of future cash flows $(\tau)$ is sufficiently high. Specifically, if $\tau=1$, then $l^{*}$ equals 0 , which is the portfolio choice that trades off simply the expected returns to bank owners from the risky asset and the safe asset. In particular, in this case both assets are fully liquid so that the optimal portfolio choice is not affected by inter-temporal liquidity considerations and consists of only risky investments.

Second, if the pledgeability of future cash flows is sufficiently low $(\tau<1)$, then liquidity cannot be generated against the full expected value of uncertain cash flows. As a result, there is an inter-temporal motive to hold liquidity. In addition, liquid holdings exceed those from the myopic portfolio choice problem as liquid assets dominate risky assets in future states where there is a strategic benefit from acquiring failed banks at cash-in-the-market prices $(k>\underline{k})$.

Finally, there is no precautionary motive for holding liquidity in our set-up. Since banks raise one unit of deposits at date 0 , the only way banks can avoid default altogether is to store the entire unit in liquid holdings, but this leaves bankowners with no residual claim after paying back deposits. We show in the appendix that regardless of the likelihood of success of the risky asset, banks never invest everything in the safe asset. This lack of liquid holdings for precautionary reasons is specific to the feature that default or lack thereof is modeled as a binomial outcome, rather than in a varying continuous fashion as the mix between safe and risky assets changes. Nevertheless, it illustrates that the motivation for liquid asset holdings can stem purely from the strategic benefit they provide to banks in acquiring failed banks. 


\subsection{Comparative statics}

In this section, we analyze how banks' choice of liquidity is affected by model parameters. We investigate the effects of the liquidity of assets in capital markets and the business cycle, which form our primary testable implications.

In developed economies, we would expect highly developed capital markets where banks can generate funds easily against future profits. Hence, one can interpret $\tau$ in our model as a proxy for the level of development in capital markets in the context of different countries. Also, when viewed in the context of a single economy, the cost of issuing capital rises, or in other words, the pledgeability of future returns, $\tau$, decreases, during economic downturns and crises. We show below that for low values of $\tau$, that is for less-developed economies and during economic downturns and crises, banks hoard more liquidity since they do not expect to have easy or cheap access to capital markets for raising funds in case profitable opportunities arise.

Also, during boom periods it is more likely that risky investments will pay off well. To this end, we consider two different probability distributions for $\alpha$, denoted as $f$ and $g$, to represent recessions and boom periods, respectively, by assuming that $g$ first order stochastically dominates (FOSD) $f$. We show that in equilibrium, banks invest less in the liquid asset during boom periods.

Combining these two results, we get the following Proposition.

Proposition 3 Let $f$ and $g$ be two probability distributions for $\alpha$, where $g$ FOSD $f$. Banks' choice of liquidity $l^{*}$ exhibits the following features:

(i) As the pledgeability of future returns, $\tau$, increases, $l^{*}$ decreases.

(ii) Let $l_{f}^{*}$ and $l_{g}^{*}$ be the liquid asset holdings of banks under probability distributions $f$ and $g$, respectively. We obtain $l_{f}^{*}>l_{g}^{*}$.

Note that from expression (11), $\phi$ is (weakly) increasing in $k$, in other words, (weakly) decreasing in $\alpha$ (see Figure 5). Increased probability of the high return has two effects on banks' choice of liquidity that work in the same direction. First, the expected return from the risky asset increases, which makes the risky asset more attractive. Also, the proportion of failed banks decreases, which limits the opportunity for making profits from asset purchases 
at cash-in-the-market prices. This, in turn, makes the liquid asset less attractive. Similarly, as $\tau$ increases, banks can generate more funds from the capital market. Hence, banks do not have to heavily rely on their liquid asset holdings which yield lower return than risky assets.

We can combine the two effects on bank liquidity in Proposition 3 by modeling the business cycle in a simple way by assuming that if $g$ FOSD $f$ then $\tau_{g}>\tau_{f}$. This assumption amplifies the effect of the business cycle on banks' choice of liquidity. Also, from Corollary 1, we know that as liquidity decreases, we observe bigger deviations in the price of banking assets from its fundamental value of $\bar{p}$. Hence, crises preceded by boom periods result in lower asset prices and higher price volatility, giving us the following result.

Corollary 2 During economic upturns, banks' choice of liquidity ${ }^{*}$ decreases. This, in turn, results in bigger deviations in the price of banking assets from their fundamental value of $\bar{p}$, that is, $\left(\bar{p}-p^{*}(k)\right)$ (weakly) increases.

\subsection{Socially optimal liquidity}

Next, we derive as a benchmark the liquidity level of banks $l^{* *}$ that maximizes the expected total output generated by the banking sector, given by

$$
E(\Pi)=E[l+(1-l)(\alpha R(l)+(1-\alpha) r)]
$$

We call this benchmark the "socially optimal" level of bank liquidity. The first-order condition for the socially optimal level of $l$ is thus given as:

$$
1-r-E(\alpha)\left[R(l)-(1-l) \frac{d R}{d l}-r\right]=0,
$$

which gives us the following Proposition.

Proposition 4 The socially optimal level of liquidity $l^{* *}$ satisfying the FOC in (15) is given as:

$$
l^{* *}=\min \left\{1, \max \left\{0,1-b+r+\frac{1-r}{E(\alpha)}\right\}\right\} .
$$

Furthermore, we have $l_{f}^{* *}>l_{g}^{* *}$, when $g$ FOSD $f$. 
The socially optimal level of liquidity is determined by only the myopic portfolio choice. In contrast to the private choice of banks, asset sales do not play a role as they simply result in transfers across banks. When $b$ increases, the return from the risky asset increases and the socially optimal level of liquidity $l^{* *}$ decreases, which can be seen from equation (16). Furthermore, $l^{* *}$ is independent of $\tau$. Note that under (A1), privately optimal liquidity $l^{*}$ is zero when $\tau$ equals one. But the socially optimal level of liquidity $l^{* *}$ may be positive. This is because while the private portfolio choice suffers from the risk-shifting problem, this is not the case for the social portfolio choice. Finally, the socially optimal liquidity is higher during recessions as was the case with privately optimal bank liquidity.

A crucial determinant of the comparison between the privately and socially optimal levels of liquidity is the extent of pledgeability of risky cash flows: When pledgeability is high, banks hold less liquidity than is socially optimal due to risk-shifting incentives, whereas when pledgeability is sufficiently low, banks may hold even more liquidity than is socially optimal. The intuition for this latter result in the context of our model is that privately banks stand to gain from acquiring failed banks in some states. However, from a social standpoint, these gains are only transfers within the banking system and there is no misallocation cost associated with asset sales within the banking sector.

The result is stated in the following proposition and is illustrated in Figure 7.

Proposition 5 There exists a critical value $\tau^{*}(E(\alpha))$, such that, the privately optimal level of liquidity is higher than the socially optimal level if and only if $\tau<\tau^{*}(E(\alpha))$.

Before we move to a discussion of the empirical support for the assumptions and the results of our model, we consider the implications of relaxing one of the assumptions. In particular, we allow the surviving banks to generate funds against the assets they acquire. This does not change our results qualitatively. In that case, the analysis is as follows. A surviving bank has $l$ units of funds from its liquid asset holdings. If this bank purchases $m$ units of assets, it can pledge a total of $\tau((1-l) R-d+m \bar{p})$ units of funds. The bank needs $m p$ units for the asset purchase. Hence, we have the financial constraint of the bank as $l+\tau((1-l) R-d+m \bar{p}) \geqslant m p$. Thus, the bank can purchase at most $m^{*}=\frac{l+\tau[(1-l) R-d]}{p-\tau \bar{p}}$ units of failed banks' assets at the price $p$. This would (weakly) increase the price for failed banks' assets compared to the benchmark model, but in general still feature cash-in-the-market prices for sufficiently high $k$. 


\section{Discussion}

\subsection{Empirical support for our key assumptions}

The following discussion provides empirical support for the key assumptions of our model such as the relevance of moral hazard in banking, the cost of raising external financing especially during distress periods, and the specificity of bank assets.

Moral hazard in banking: Our model relies on the feature that bank-level moral hazard is addressed by greater ownership of the bank by insiders. This assumption finds considerable empirical support in cross-country data on bank ownership. Caprio, Laeven and Levine (2005) study the ownership patterns of 244 banks across 44 countries, collecting data on the 10 largest publicly listed banks in those countries. They document that banks in general are not widely held (where a widely-held bank is one in which no legal entity owns 10 percent or more of the voting rights), a finding that is similar to that of La Porta, Lopez de Silanes and Shleifer (1999) for corporations in general. In particular, Caprio et al. document that inside ownership of banks (especially by families that are found to have controlling stakes more than half of the time in the average country) and ownership by the state is more commonly observed than a dispersed ownership of banks, which is found in less than 25 percent of the banks. This observation is stronger in those countries which have weaker shareholder protection laws. ${ }^{13}$ Importantly, they also find that greater inside ownership of banks enhances bank valuation, especially in those countries where the shareholder protection laws are weaker.

Overall, these findings are consistent with the moral hazard aspects of our model since weaker shareholder protection laws should imply a greater risk of cash-flow appropriation by insiders, and, in turn, lead to greater inside ownership of banks in equilibrium. At the same time though, this evidence makes it clear that our model may not be literally applicable to countries with strong shareholder protection since their banks are indeed widely held. In such countries, the relevant moral hazard is likely to be at the level of bank managers. There is evidence that such managerial moral hazard is an important determinant of bank performance and failures. A study completed in 1988 by the Office of the Comptroller of

\footnotetext{
${ }^{13}$ For example, more than 90 percent of the banks in Canada, Ireland, and the United States are widely held, but not more than 50 percent in Italy, Spain and Venezuela are widely held. A significant proportion of the remaining ones are controlled by families, whereas 21 out of 44 countries (for example, Argentina, Brazil, Chile, Israel, Mexico and Thailand) do not have a single widely held bank among their largest banks.
} 
the Currency in the United States, based on 171 banks that failed, became distressed and recovered, or remained healthy during the period 1979-1987, identified characteristics and conditions present when the banks' health deteriorated. The study found that "Managementdriven weaknesses played a significant role in the decline of 90 percent of the failed and problem banks the OCC evaluated". The study also concluded that principal-agent problems within banks are a key reason for bank failures in addition to deteriorating quality of assets during business downturns. Our model does not explicitly consider incentive contracts for managers of widely held banks, but the moral-hazard problem we study can be considered as a metaphor for a general class of principal-agent problems affecting banks.

Costly external finance: Perhaps an important limitation of the moral hazard based approaches to modeling the limited liquidity of banks (and, firms in general) is that in practice asymmetric information issues are clearly pertinent. Our focus on moral hazard is driven primarily by tractability, as in a large body of theoretical literature, especially since Holmstrom and Tirole (1998).

Regardless, it is evident that there are costs to raising external finance, especially during crises, even for banks and firms in economies with strong shareholder protection. While some of these costs, such as those of equity issuance, arise due to the asymmetric information problem (the so-called "dilution" cost of external finance, as in Myers and Majluf, 1984), there are significant costs even in secured borrowing during such times. The issues are best illustrated in the initial margins (or "haircuts") demanded by borrowers in collateralized lending agreements, such as in repurchase agreements (repos). ${ }^{14}$ It is found empirically that the haircut fluctuates with funding conditions in the market, and largely determines the financing capacity of an individual financial institution. The fact that times of financial stress are associated with sharply higher haircuts, is shown succinctly in the October 2008 issue of the Global Financial Stability Report of the International Monetary Fund (IMF (2008)), which shows the haircuts in secured lending transactions at two dates, in April 2007 before the financial crisis and in August 2008 in the midst of the crisis. Haircuts are substantially higher during the crises than before. For further empirical evidence see footnote on page 2.

\footnotetext{
${ }^{14}$ In a repurchase agreement, the borrower sells a security today for a price below the current market price on the understanding that it will buy back the security in the future at a pre-agreed price. The difference between the current market price of the security and the price at which it is sold is called the "haircut" in the repo.
} 
This illustrates the fact that the imperfect pledgeability of assets in borrowing transactions arises during stress periods even in market settings where the collateral assets are commonly traded securities and even for reasonably large financial institutions.

\subsection{Empirical support for our results}

In this section, we provide some anecdotal and descriptive empirical evidence that is consistent with the model's implications for liquidity holdings of banks.

Hoarding of liquidity by banks for gains during crises: We focus below on one salient historical anecdote of a bank hoarding liquidity for strategic gains during crises - that of National City Bank from the United States during the pre-Federal Reserve era. ${ }^{15}$

Cleveland and Thomas, in their book Citibank, provide a memorable account of how National City Bank, that eventually became Citibank, grew from a small treasury unit into one of the biggest commercial banks under its president Stillman, who anticipated the 1893 and 1907 crises and built up liquidity and capital before the crises to benefit from the difficulties of its competitors. In terms of actual levels of bank liquidity, the reserve ratio of National City Bank was 42.6\% and 26.9\% right before the 1893 and 1907 crises, respectively, while these ratios were lower at $25.2 \%$ and $24.9 \%$ for all other New York City banks. Also, for the 1907 crisis, the capital to net deposits stood at 35.2\% for National City Bank, whereas it was $27.5 \%$ for all other New York City banks.

What was the impact of such positioning by National City Bank of the balance-sheet in terms of cash and capital? Cleveland and Thomas report that during the 1893 (1907) crises, while National City Bank increased its deposits by $12.4 \%$ (23.5\%), deposits in all other New York City banks decreased by $14.5 \%$ (increased by only $9.2 \%$ ). Furthermore, during the 1893 (1907) crises, while National City Bank increased its loans and discounts by 14.7\% $(10.2 \%)$, loans and discounts in all other New York City banks decreased by $9.1 \%$ (increased by only 3.7\%). In other words, evidence shows that National City Bank expanded its business operations while other banks were simultaneously experiencing a shrinkage. We document

\footnotetext{
${ }^{15}$ Casual empiricism suggests however that such cases are not uncommon. In fact, our private communications with bankers suggest that during the most recent sub-prime crisis of 2007-2009 too, one of the perceived reasons for drying up of inter-bank lending markets has been the hoarding of liquidity by banks for acquisitions of troubled institutions at fire-sale prices, the other two reasons being precautionary motive from the risk of being distressed oneself and adverse selection about borrowing institutions.
} 
below that hoarding liquidity to acquire business that belonged to distressed institutions (in case of 1907 crisis, the New York-based trusts) was indeed the strategy followed by the bank. Below is the paragraph about the 1907 crisis from Cleveland and Thomas' book (page 52) which illustrates this point succinctly:

National City Bank again emerged from the panic a larger and stronger institution. At the start, National City had higher reserve and capital ratios than its competitors, and during the panic it gained in deposits and loans relative to its competitors. Stillman (President) had anticipated and planned for this result. In response to Vanderlip's (Vice President) complaint in early 1907 that National City's low leverage and high reserve ratio was depressing profitability, Stillman replied: "I have felt for sometime that the next panic and low interest rates following would straighten out good many things that have of late years crept into banking. What impresses me most important is to go into next Autumn (usually a time of financial stringency) ridiculously strong and liquid, and now is the time to begin and shape for it... If by able and judicious management we have money to help our dealers when trust companies have suspended, we will have all the business we want for many years."

In our paper, we focus for simplicity on a symmetric equilibrium, where ex ante all banks hold the same portfolio. However, ex post, we observe heterogeneity among banks, that is, we have some banks that fail and are forced to sell their assets, and banks that are healthy (like National City was in 1893 and 1907) use their liquidity buffers to acquire failed banks.

Bank liquidity and ease of external finance: To provide more systematic evidence on bank liquidity, we appeal to the implication of our analysis that the greater is the difficulty banks face in raising external finance, the more would banks hold liquid assets. We explore this hypothesis by examining the liquid asset holdings of banks in a cross-section of countries.

In a recent paper, Freedman and Click (2006) show that banks in developing countries choose to channel only a modest portion of their funds to private sector borrowers, while keeping a sizeable percentage of their deposits in liquid assets, such as cash, deposits with other banks, central bank debt, and short-term government securities. They construct a liquidity ratio for banks, defined as the ratio of Liquid Assets to Total Deposits, using International Financial Statistics provided by the IMF. ${ }^{16}$ They show that for developing countries

\footnotetext{
${ }^{16}$ In particular, they calculate Liquid Assets as the sum of Reserves (line 20) and Claims on Central Government (usually line 22A), and Total Deposits as the sum of Demand Deposits (line 24), Time and Savings Deposits (line 25), Money Market Instruments (line 26A), and Central government Deposits (line
} 
the ratio ranges from $14 \%$ in South Africa to $126 \%$ in Argentina, with a mean value of $45 \%$, with values of $2 \%$ for the UK, $6 \%$ for the US, $21 \%$ for Japan, $31 \%$ for France and $34 \%$ for Germany, with an average of $19 \%$ for developed countries.

They attribute this difference among developed and developing countries to banks' reluctance to lend in developing countries. Such reluctance, they argue, could be a response to inefficiencies in credit markets resulting from factors such as higher reserve requirements, greater macroeconomic risk and volatility, and significant deficiencies in the legal and regulatory environment which make it difficult to enforce contracts and foreclose on collateral. In this paper, we argue that an alternative channel may also be at work. Banks in poor legal and regulatory environments may find it difficult to raise liquidity against future profits and thus end up hoarding greater liquidity. Such cash hoardings may be inefficiently high and result in low levels of intermediation by the banking sector.

We expand on the data set of Freedman and Click (2006) to cover about 70 countries with data on liquidity ratios dating back to September 2003. First, we link bank liquidity to a number of institutional variables that capture country's financial development in terms of quality of disclosures, and the extent of stock and credit intermediation (relative to country's size). These proxies should thus all measure the ease of raising external finance.

Specifically, we employ five measures based on Rajan and Zingales (1998, 2003), which are: (1) accounting standards, (2) total capitalization to GDP, (3) domestic credit to GDP, (4) deposits to GDP, and (5) stock market capitalization to GDP. ${ }^{17}$

We find that in the cross-section of countries, the correlation of country-level average for the banking system's ratio of Liquid Assets to Total Deposits with these five measures is uniformly and significantly negative, the values being $-0.55,-0.38,-0.36,-0.33$, and -0.50 , respectively. We also plot the best regression fit of the Liquidity Ratio to Accounting 26D).

${ }^{17}$ The measures we employ are as follows: (1) Accounting standards is an index developed by the Center for International Financial Analysis \& Research ranking the amount of disclosure in annual company reports in each country. Though this index from Rajan and Zingales dates back to 1990, they report that it does not change much over time. (2) Total capitalization to GDP is the ratio of the sum of equity market capitalization (as reported by the IFC) and domestic credit (IFS line 32a-32f but not 32e) to GDP. Stock market capitalization is measured at the end of the earliest year in the 1980's for which it is available. (3) Domestic credit to GDP is the ratio of domestic credit to the private sector, which is from IFS line $32 \mathrm{~d}$, over GDP. (4) Deposits to GDP is the ratio of domestic deposits to the GDP, based on data for 1999. (5) Stock market capitalization to GDP is the ratio of the aggregate market value of equity of domestic companies divided by GDP, based on data for 1999 . 
standards (Figure 8) and to Total capitalization to GDP (Figure 9). The graphs illustrate that the negative relationship is quite robust to exclusion of outliers such as Argentina, whose liquidity ratio has been inflated due to the economic and political turmoil following its default in 2001.

While this evidence is striking, it is potentially also consistent with the explanation that these measures of financial development (especially Domestic credit to GDP and to some extent Accounting standards) also proxy for frictions in the market for lending. That is, the negative relationship may be due to lower attractiveness of risky loans in these countries rather than due to greater attractiveness of safe assets. To help at least partially address this issue, we examine data on international stock market liquidity measured over the period 1989 to 2000 from Levine and Schmukler (2005). In particular, we consider for a subset of countries three measures of stock-market liquidity, namely Turnover in Domestic Market, and two inverse proxies, Illiquidity Ratio of Amihud (2002), and Proportion of Zero Return Days advocated by Bekaert, Harvey and Lundblad (2003).

While the first two measures show little correlation with the banking-system liquidity ratio, we find that the third measure of stock-market illiquidity, the proportion of zero return days, is significantly positively correlated. The correlation is 0.25 (Figure 10 shows the best regression fit of banks' Liquidity Ratio versus the Proportion of Zero Return Days). When the Brazil outlier is excluded, the correlation is around 0.35, the corresponding correlations with Accounting standards and Total Capitalization to GDP being -0.25 and -0.60 , respectively (for the limited sample where stock market liquidity proxies are available).

This suggests that the relationship between financial development and bank liquidity may not entirely be due to credit-market frictions. A part of this relationship may also stem from the fact that financial development is associated with greater ease of external finance, which reduces the attractiveness of liquidity in banks' portfolio choice. Overall, this crosscountry evidence is suggestive, even if not conclusive, that the hoarding of liquidity buffers for profitable investments such as acquisitions may be a potentially important determinant of equilibrium levels of bank liquidity.

Bank liquidity and the business cycle: In order to provide further evidence in support of our model's implications, we next appeal to the implication that bank liquidity is countercyclical, that is, lower during economic upturns and higher as recessions approach (or are anticipated). On this implication, we rely on extant empirical evidence. 
Aspachs et al. (2005) analyze the determinants of UK banks' liquidity holdings and find evidence supportive of this hypothesis. They use balance sheet and profit and loss data, for a panel of 57 UK-resident banks, on a quarterly basis, over the period 1985Q1 to 2003Q4. These data are obtained from the Bank of England Monetary and Financial statistics and relate to the banks' resident (UK) activity, excluding activities abroad. They measure liquidity as the sum of cash, reverse Repos, bills and commercial papers and comprise in addition all types of investment securities, such as equities and bonds. They use two alternative liquidity ratios. The first is the share of liquid assets in the bank's total assets. This measure captures the split between liquid and illiquid assets on the bank's balance sheet. And, to capture the liquidity mismatch inherent in the bank's balance sheet, they use a second measure, which is the ratio of liquid assets to total deposits. However, their results do not change materially whether they use the ratio of liquidity over assets, or the ratio of liquidity over deposits.

In their regression analysis, they test among other effects the role of GDP growth in determining banks' liquid asset holdings. They find that banks in the UK appear to hold smaller (larger) amounts of liquidity, relative to both total assets and total deposits, in periods of stronger (weaker) economic growth. In particular, a 1\% increase in GDP growth results in about a $2 \%$ decrease in liquidity, where the effect is significant at the $1 \%$ level. In other words, banks appear to build up their liquidity buffers during economic downturns and draw them down in economic upturns. Again, while business cycle fluctuations are certainly associated with fluctuations in demand for risky loans, this evidence, put together with the cross-country evidence, provides preliminary support for our model's hypotheses. More research differentiating the alternative determinants of banks' liquid asset holdings is certainly warranted.

\section{Entry, inefficient liquidations and resolution policy}

We revert to the theoretical analysis of liquidity choice of banks. In the benchmark model, only banks are present in the market for purchasing banking assets. In this section, we analyze the effect of entry by outsiders for purchase of distressed assets. One interpretation of these outsiders is as non-bank financial institutions such as hedge funds. ${ }^{18}$

\footnotetext{
${ }^{18}$ The article entitled "Cashing in on the crash" in the Economist on August 23, 2007, provides a discussion of the incentives to hold liquidity for hedge funds to take advantage of fire sales during the recent financial turmoil. The article argues that vulture funds raised $\$ 15.1$ billion in the first seven months of 2007 , more
} 
Formally, we introduce outside investors who are risk-neutral and competitive and have funds of $w$ to purchase banking assets were these assets to be liquidated. These are investors outside the banking sector, and even though they have funds for asset purchases, they do not have the skills to generate the full value from banking assets. Hence, outsiders are assumed to be inefficient users of banking assets relative to bank owners, provided that bank owners exert effort. Often such outsiders are short-term holders who re-package or securitize the assets for selling to portfolio investors. Such outsiders may be unable to realize the full value of assets for the familiar reason that bank assets (loans in particular) derive much of their value from the monitoring and collection efforts of loan officers who can influence the actions of the debtors. Hence, when distressed assets end up in the hands of outsiders, we may expect deadweight costs from inefficient allocation of assets. To capture this formally, we assume that outsiders cannot generate $r$ in the low state but only $(r-\Delta)$. We also assume that $\bar{\Delta}>\Delta>0$ so that outsiders can generate more than what banks can generate when they choose bad projects.

The notion that outsiders may not be able to use the banking assets as efficiently as the existing bank owners is akin to the notion of asset-specificity, first introduced in the corporate-finance literature by Williamson (1988) and Shleifer and Vishny (1992) and employed extensively since then in the banking literature as well. ${ }^{19}$ In the evidence of such specificity for banks and financial institutions, James (1991) shows that the liquidation value of a bank is typically lower than its market value as a going concern. In particular, his empirical analysis of the determinants of the losses from bank failures reveals a significant difference in the value of assets that are liquidated and similar assets that are assumed by acquiring banks.

We assume that $w<\underline{p}$. This implies that liquidity with outsiders is small enough that for sufficiently large number of bank failures, there is an aggregate shortage of liquidity in the

than the $\$ 13.9$ billion in all of 2006 , to acquire assets at fire-sale discounts due to expected distress in financial markets. The same article points out that while some hedge funds suffered as the sub-prime crisis unfolded in the Summer of 2007, the others, such as Citadel, Ellington, and Marathon Asset Management had the ready cash to benefit from the crisis. For example, the article highlights the strategy of Citadel to keep more than a third of its assets in cash or liquid securities, allowing it to take advantage of fire sales when opportunities arise.

${ }^{19}$ There is strong empirical support for the idea of asset specificity in the corporate-finance literature, as shown, for example, by Pulvino (1998) for the airline industry, and by Acharya, Bharath, and Srinivasan (2006) for the entire universe of defaulted firms in the US over the period 1981 to 1999 (see also Berger, Ofek, and Swary, 1996, and Stromberg, 2000). 
market for purchasing assets. The liquidity shortage is aggregate in the sense that if almost all banks fail, then the amount of outsider wealth necessary to ensure there are no fire-sale gains for outsiders is $\underline{p}$, but for $w<\underline{p}$, outsiders gain from acquisitions in at least some states of the world. This assumption is natural as in the absence of any strategic gains in future, it would not be optimal for outsiders to park such capital in cash hoardings for ready deployment for acquisitions. Outside of our setup, capital set aside for such "arbitrage" may also be limited due to potential risks in undertaking and implementing arbitrage (Shleifer and Vishny, 1997). Analysis of how much outside capital will optimally be held in equilibrium is beyond the scope of the current paper. Allen and Gale (2004a,b), Gorton and Huang (2004) and Acharya, Shin and Yorulmazer (2009) derive both the endogeneity of limited outside capital and its equilibrium level.

To start with, we assume that outsiders employ their capital only to acquire assets and not to provide finance to surviving banks. This assumption is made purely for simplicity and we discuss relaxing it later. In terms of analysis, we first examine the sale of failed banks and the resulting prices in the presence of outsiders. The demand schedule for surviving banks does not change and we can derive the demand schedule for outsiders in a similar way. Let $\underline{p} \equiv \bar{p}-\Delta$, be the expected return for outsiders from the risky asset in the second period. For $p<\underline{p}$, outsiders are willing to supply all their funds for the asset purchase. Thus, demand schedule is $y_{2}(p)=k$. For $p>\underline{p}$, the demand is $y_{2}(p)=0$, and for $p=\underline{p}$, outsiders are indifferent between $y_{2}(p)$ over the range $[0, k]$. Thus, for $p>\underline{p}$, there is limited participation in the market for banking assets in that only insiders submit positive bids to purchase assets.

Next, we analyze how the regulator optimally allocates failed banks' assets. In the absence of financial constraints faced by surviving banks, it is optimal to sell all assets to surviving banks. However, surviving banks may not be able to pay the threshold price of $\underline{p}$ for all assets, and if prices fall further, these assets become profitable for outsiders and they participate in the auction. Formally, for $k>\bar{k}$, where

$$
\bar{k}=\frac{L}{L+(1-l) \underline{p}},
$$

surviving banks cannot pay the threshold price of $\underline{p}$ for all assets, and outsiders are willing to supply all their funds for the asset purchase. With the injection of outsider funds, the price is sustained at $\underline{p}$ for a range of $k$ values. However, since $w<\underline{p}$, if the crisis is very severe (sufficiently large $k$ ), the total liquidity available within the surviving banks and outsiders is not enough to sustain the price at $\underline{p}$. Thus, we observe a second region where the price is 
downward sloping as a function of $k$. In other words, there is cash-in-the-market pricing in this region given the limited liquidity of the entire set of market players bidding for assets. In particular, for $k>\overline{\bar{k}}$, where

$$
\overline{\bar{k}}=\frac{L+w}{L+(1-l) \underline{p}},
$$

the price is again strictly decreasing in $k$ and is given by

$$
p_{w}^{*}(k)=\frac{(1-k) L+w}{(1-l) k},
$$

and $y\left(p_{w}^{*}\right)=\frac{L}{p_{w}^{*}}$ and $y_{2}\left(p_{w}^{*}\right)=\frac{w}{p_{w}^{*}}$. The resulting price function is illustrated in Figure 11 and is stated in the following proposition.

Proposition 6 The price of assets as a function of the proportion $k$ of failed banks and outsiders' wealth $w$ is:

$$
p_{w}^{*}(k)=\left\{\begin{array}{ccc}
\bar{p} & \text { for } & k \leqslant \underline{k} \\
\frac{(1-k) L}{(1-l) k} & \text { for } & k \in(\underline{k}, \bar{k}] \\
\underline{p} & \text { for } & k \in(\bar{k}, \overline{\bar{k}}] \\
\frac{(1-k) L+w}{(1-l) k} & \text { for } & k>\overline{\bar{k}}
\end{array} .\right.
$$

Note that the introduction of outsiders (weakly) increases the price for failed banks. In particular, for $k>\bar{k}$, with the injection of outsider funds, the price $p_{w}^{*}(k)$ is higher than the price without outsiders. This implies that the expected benefit to banks from holding the liquid asset to purchase assets declines. In this case, bank $i$ 's problem can be stated in the same way as in the benchmark case (equation (9)), except for the fact that instead of $\phi$, we have

$$
\phi_{w}=\alpha\left[\frac{\bar{p}-p_{w}^{*}(k)}{p_{w}^{*}(k)}\right],
$$

as the expected benefit from asset purchase per unit of liquidity. Note that for $k \leqslant \bar{k}, \phi_{w}=\phi$, whereas for $k>\bar{k}$, we have $\phi_{w}<\phi$. Since $E\left(\phi_{w}\right)<E(\phi)$, the unique aggregate level of bank liquidity $l_{w}^{*}$ with outsiders is lower than $l^{*}$ given in Proposition $2 .^{20}$

\footnotetext{
${ }^{20}$ We observe a similar effect of $\Delta$ on banks' choice of liquidity as before. As the wedge between the expertise of banks and outsiders widens, that is, as $\Delta$ increases, the price for assets weakly decreases for all $k>\bar{k}$. This, in turn, increases $\phi_{w}$ and banks hold more liquidity.
} 
Note that for $k \leqslant \overline{\bar{k}}$, the price for failed banks' assets is $\underline{p}$ and outsiders do not make any profits from asset purchases. Hence, if we allow surviving banks to issue shares to outsiders to generate funds, they can sell each unit of share for the full price of $\bar{p}$. However, for $k>\overline{\bar{k}}$, the price for failed banks' assets falls below $\underline{p}$ and outsiders make positive profits from asset purchases. In equilibrium, the rates of return outsiders earn from financial and real assets must be the same. So the key determinant of equilibrium prices and allocation efficiency is how much outside capital reaches surviving banks through financial markets. However, due to agency problems, the extent of such financing of insiders is necessarily limited. Or in other words, in states with aggregate liquidity shortage $(k>\overline{\bar{k}})$, both the market for control of assets and the market for external finance must experience fire sales; surviving banks can only issue finance at dilutive costs; and in equilibrium, outsiders continue to make acquisition of at least some assets of failed banks. Complete details of this rich analysis are available in Acharya, Shin and Yorulmazer (2009).

Reverting for simplicity to the first case where outside capital is deployed only for purchase of assets, the socially optimal liquidity level $l$ of each bank maximizes the objective function

$$
E(\Pi)=E[l+(1-l)[\alpha R(l)+(1-\alpha) r]]-\Delta \int_{\bar{k}}^{1} f(k)\left[(1-l) k-\frac{(1-k) L}{p_{w}^{*}(k)}\right] d k
$$

where $\left[(1-l) k-\frac{(1-k) L}{p_{w}^{*}(k)}\right]$ represents the units of assets purchased by outsiders at the price $p_{w}^{*}(k)$, which, multiplied by $\Delta$, gives the misallocation cost arising from outsiders' lack of expertise relative to banks. Hence, for $k>\bar{k}$, the regulator may choose to intervene to prevent the misallocation cost resulting from sales to outsiders.

Next, we analyze the effect of different resolution policies on banks' choice of liquidity holdings. In particular, the regulator may choose to let failed banks continue ("bailout") or acquire failed banks' assets and hold them until maturity, where both policies have the same effect of reducing the fire-sale opportunities for surviving banks. The regulator may also provide liquidity to surviving banks so that these banks have enough funds to purchase all failed banks' assets. To keep the analysis simple, we assume that the misallocation cost from sales to outsiders is high enough so that the regulator would like to employ one of these policy options to avoid any misallocation cost. Since our focus is on the effect of different policies on ex-ante bank liquidity, we assume that failed banks and the regulator can generate the same value from assets as can the surviving banks. Possible inefficiencies in the continuation 
value of assets under different policies will affect ex-post welfare and the relative desirability of different policies. ${ }^{21}$

Bank bailouts or regulatory acquisition of failed banks' assets: The regulator can buy some of the failed banks' assets so that the surviving banks can buy all of the remaining failed banks' assets at the price $\underline{p}$. Alternatively, the regulator can allow failed banks to continue, effectively bailing them out. Both policies prevent sales to outsiders and avoid any misallocation of banking assets. In particular, when the regulator acquires a sufficient proportion of failed banks' assets, the price for failed banks' assets can be sustained at $\underline{p}$ by surviving banks' liquidity and no assets need to be sold to outsiders.

Surviving banks can acquire $\frac{\bar{L}(k)}{\underline{p}}$ units of failed banks' assets at the price $\underline{p}$, where $\bar{L}(k)=$ $(1-k) L$ is the total liquidity within the set of surviving banks, and the regulator acquires the rest of the failed banks' assets, denoted as $b(k) \equiv(1-l) k-\frac{\bar{L}}{\underline{p}}$ units. In this case, the price for failed banks' assets is given as:

$$
p_{b}(k)=\left\{\begin{array}{clc}
\bar{p} & \text { for } & k \leqslant \underline{k} \\
\frac{(1-k) L}{(1-l) k} & \text { for } & k \in(\underline{k}, \bar{k}] \\
\underline{p} & \text { for } & k>\bar{k}
\end{array} .\right.
$$

Thus, each banks' problem is to choose $l$ that maximizes

$$
E(\pi(l))=E\left(\alpha\left[[l+(1-l) R(l)-d]+L\left(\frac{\bar{p}-p_{b}(k)}{p_{b}(k)}\right)\right]\right) .
$$

In this case, banks' problem can be stated in the same way as in the case with the entry of outsiders earlier, except for the fact that instead of the private benefit to banks from liquidity being $\phi_{w}$, it is given by

$$
\phi_{b} \equiv \alpha\left[\frac{\bar{p}-p_{b}(k)}{p_{b}(k)}\right]
$$

For $k \in(\bar{k}, \overline{\bar{k}}]$, acquisitions by the regulator do not affect the price, which will be $\underline{p}$. Hence, in this region, the private benefit to banks from holding the liquid asset does not change,

\footnotetext{
${ }^{21}$ For a detailed normative analysis of resolution policies, see Acharya and Yorulmazer (2008), which also allow for the possibility that the regulator may find it desirable to incur some misallocation cost, for example, if the fiscal costs incurred in providing public liquidity to the banking sector is increasing, especially in a convex fashion, in the amount of liquidity support.
} 
that is, $\phi_{b}=\phi_{w}$. In other words, failed banks that would have been acquired by outsiders are now being acquired by the regulator and this does not have an effect on the private gain from asset purchases for the surviving banks. However, for $k>\overline{\bar{k}}$, acquisitions by the regulator increase the price to $\underline{p}$. This, in turn, decreases the benefit from holding liquidity to buy banking assets at fire-sale prices, that is, $\phi_{b}<\phi_{w}$. Hence, bailouts and asset acquisitions by the regulator induce banks to hold less liquidity.

Unconditional liquidity provision to surviving banks: Alternatively, the regulator can grant liquidity to surviving banks so that they have enough funds to purchase all failed banks' assets at the price $\underline{p}$. This would also avoid any allocation inefficiency.

For $k>\bar{k}$, surviving banks have a total liquidity of $\bar{L}(k)=(1-k) L$, whereas the total liquidity needed to acquire all failed banks' assets at the price $\underline{p}$ is $(1-l) k \underline{p}$. Hence, the regulator needs to provide surviving banks $\widehat{L}(k)=(1-l) k \underline{p}-\bar{L}(k)$ units of liquidity to prevent sales to outsiders. In the unconditional liquidity provision policy, for $k>\bar{k}$, the regulator distributes $\widehat{L}(k)$ units of liquidity equally among surviving banks, regardless of their liquidity position at the time of resolution, so that each surviving bank is granted $\widehat{l}(k)$ units, where

$$
\widehat{l}(k)=\left\{\begin{array}{cc}
0 & \text { for } k \leqslant \bar{k} \\
\frac{(1-l) k \underline{p}}{1-k}-L & \text { for } k>\bar{k}
\end{array} .\right.
$$

Thus, surviving bank $i$ has $\widehat{l}(k)+L_{i}$ units of liquidity for the asset purchase so that it can acquire $\frac{\widehat{l}(k)+L_{i}}{p_{b}(k)}$ units of failed banks' assets, making a profit of $\left[\left(\widehat{l}(k)+L_{i}\right)\left(\frac{\bar{p}}{p_{b}(k)}\right)-L_{i}\right]$. Effectively, the bank spends only $L_{i}$ units of its own funds. Thus, bank $i$ 's problem is to choose $l_{i}$ that maximizes

$$
E\left(\pi_{i}\left(l_{i}\right)\right)=E\left(\alpha\left[\left[l_{i}+\left(1-l_{i}\right) R\left(l_{i}\right)-d\right]+L_{i}\left(\frac{\bar{p}-p_{b}(k)}{p_{b}(k)}\right)+\widehat{l}(k)\left(\frac{\bar{p}}{p_{b}(k)}\right)\right]\right) .
$$

The last term is the expected profit from the asset purchase using the liquidity $\widehat{l}(k)$ granted by the regulator, which is independent of bank $i$ 's liquidity. Since the price for the failed banks' assets is the same as in equation (23), the FOC for banks' problem is also the same as in the case with bailouts and regulatory acquisition of failed banks' assets. Thus, unconditional liquidity provision policy induces banks to hold less liquidity.

Conditional liquidity provision to surviving banks: Another resolution policy is to grant liquidity to each surviving bank conditional on the amount of liquidity each surviving 
bank has. Note that, as in the unconditional liquidity provision policy, the total liquidity that needs to be provided by the regulator to prevent sales to outsiders is $\widehat{L}(k)=(1-l) k \underline{p}-\bar{L}(k)$. In this case, the regulator provides each surviving bank a proportion $z=\frac{\widehat{L}(k)}{\bar{L}(k)}$ of the liquid assets the surviving bank has, that is, surviving bank $i$ receives $\widetilde{l}_{i}(k)$ units of liquidity, where

$$
\widetilde{l}_{i}(k)=\left\{\begin{array}{ccc}
0 & \text { for } & k \leqslant \bar{k} \\
z L_{i} & \text { for } & k>\bar{k}
\end{array} .\right.
$$

This way, the regulator provides a total liquidity of $\widehat{L}(k)$ units to surviving banks, just enough to prevent sales to outsiders.

With this policy, for $k>\bar{k}$, the regulator subsidizes asset sales to surviving banks and each surviving bank acquires $\frac{(1+z) L_{i}}{\underline{p}}$ units of assets by using their liquidity $L_{i}$ at an effective price of $\widetilde{p}(k)$ for each unit, where

$$
\widetilde{p}(k)=\left\{\begin{array}{ccc}
\bar{p} & \text { for } & k \leqslant \underline{k} \\
\frac{(1-k) L}{(1-l) k} & \text { for } & k \in(\underline{k}, \bar{k}] . \\
\frac{\underline{p}}{1+z} & \text { for } & k>\bar{k}
\end{array}\right.
$$

Thus, bank $i$ 's problem is to choose $l_{i}$ that maximizes ${ }^{22}$

$$
E\left(\pi_{i}\left(l_{i}\right)\right)=E\left(\alpha\left[\left[l_{i}+\left(1-l_{i}\right) R\left(l_{i}\right)-d\right]+L_{i}\left(\frac{\bar{p}-\widetilde{p}(k)}{\widetilde{p}(k)}\right)\right]\right) .
$$

In this case, we can show that the strategic benefit to banks of holding the liquid asset is given by

$$
\widetilde{\phi}=\alpha\left(\frac{\bar{p}-\widetilde{p}(k)}{\widetilde{p}(k)}\right) .
$$

Note that for $k \leqslant \bar{k}$, we have $\widetilde{\phi}=\phi_{w}$ and for $k>\bar{k}$, we have $\widetilde{\phi}>\phi_{w}$. Hence, the strategic benefit of holding the liquid asset is higher in this case compared to the case without the liquidity provision policy (and, in turn, higher compared to the bailout and unconditional liquidity provision policies). This implies that under the conditional liquidity provision policy, banks have incentives to hold more of the liquid asset.

\footnotetext{
${ }^{22}$ Alternatively, we can write the profit from asset purchases as $\left(L_{i}+\widetilde{l}_{i}(k)\right)\left(\frac{\bar{p}}{p_{b}(k)}\right)-L_{i}$, which is equivalent to $L_{i}\left(\frac{\bar{p}-\widetilde{p}(k)}{\tilde{p}(k)}\right)$.
} 
We have shown that different regulatory policies can have rather different effects on banks' choice of liquidity. Hence, depending on whether banks hold too much or too little liquidity compared to the socially optimum level, the regulator can employ different policies. In particular, the regulator can employ the first two policies to unlock banks' liquidity reserves, or create incentives for banks to hold more liquidity by employing the conditional liquidity provision policy. The optimal design of resolution policies that account for the ex-ante effects on bank liquid holdings is thus subtle and deserves further attention. To summarize, we obtain that

Proposition 7 The effect of bank resolution policies on bank liquidity holdings is as follows:

(i) Bailouts and regulatory acquisition of failed banks' assets (weakly) increase the price for failed banks' assets and therefore decrease banks' ex-ante incentives to hold liquidity.

(ii) Unconditional liquidity provision to surviving banks (weakly) increases the price for failed banks' assets and decreases banks' incentives to hold liquidity.

(iii) Liquidity provision to surviving banks conditional on their liquidity level also (weakly) increases the price for failed banks' assets but increases banks' incentives to hold liquidity.

Costly deposit insurance and liquidity provision: In the analysis of the regulatory policies so far, the public provision of deposit insurance and liquidity did not entail any fiscal costs. In practice, the public provision of funds may result in significant fiscal costs for economies. These fiscal costs may be linked to a variety of sources, such as (i) distortionary effects of tax increases required to fund regulatory expenditures; (ii) the likely effect of huge government deficits on the country's exchange rate, manifested in the fact that banking crises and currency crises have often occurred as twin crises in many countries. Ultimately, the fiscal cost we have in mind is one of immediacy: government expenditures and inflows during the regular course of events are smooth, relative to the potentially rapid growth of off-balance-sheet contingent liabilities such as deposit-insurance funds, costs of bank bailouts, etc. $^{23}$

\footnotetext{
${ }^{23}$ See, for example, the discussion on fiscal costs associated with banking collapses and bailouts in Calomiris (1998). Hoggarth, Reis and Saporta (2002) find that the cumulative output losses have amounted to a
} 
When a bank fails, it owes $d$ units to its depositors. It has $l$ units of liquidity and the remaining $(d-l)$ units are paid to depositors by the deposit insurance fund. The regulator collects proceeds from the sale of assets to cover some of the costs of providing deposit insurance. Hence, the regulator needs to come up with $\left(d-l-p^{*}(k)\right)$ units of funds. Suppose that the regulator faces the cost function $c(x)$, when the deposit insurance fund provides $x$ units of funds, with $c^{\prime}>0$ and $c^{\prime \prime} \geqslant 0$. For example, $c(x)=a x^{2}$, with $a>0$.

Given these assumptions, there are two effects that are important. First, with a fiscal cost of deposit insurance, a social cost is incurred whenever a bank fails regardless of whether the number of bank failures is high enough to result in sales to outsiders. Since funds to be provided by the deposit insurer decrease in the liquidity carried by failed banks, the socially optimal level of liquidity increases in the fiscal cost parameter (for example $a$ ). Second, the fiscal cost incurred is increasing in the number of bank failures for two reasons: first, simply because more banks have failed, and second, because with fewer surviving banks there is lower overall liquidity and hence lower proceeds for the regulator from the sale of failed banks. Hence, the fiscal cost of providing deposit insurance and liquidity unambiguously raises the socially optimal level of liquidity. In turn, with costly deposit insurance and liquidity provision the range of parameter values for which the socially optimal level of liquidity is higher than the privately optimal level increases.

\section{Concluding remarks}

Our objective in this paper has been to develop a theoretical framework for bank portfolio choice between liquid (safe) and illiquid (risky) assets that is driven by a strategic acquisition motive. We have focused somewhat narrowly on the implications of this strategic motive, but it remains an important empirical question to differentiate and measure its importance relative to the more traditional precautionary motive for holding liquidity. While our positive analysis of determinants of bank liquidity lends itself naturally to empirical work, of greater consequence for policy is our normative analysis comparing the equilibrium liquidity choice

whopping 15-20 percent of annual GDP in the banking crises of the past 25 years. Caprio and Klingebiel (1996) argue that the bailout of the thrift industry cost $\$ 180$ billion (3.2 percent of GDP) in the US in the late 1980s. They also document that the estimated cost of bailouts were 16.8 percent for Spain, 6.4 percent for Sweden and 8 percent for Finland. Honohan and Klingebiel (2000) find that countries spent 12.8 percent of their GDP to clean up their banking systems whereas Claessens, Djankov and Klingebiel (1999) set the cost at 15-50 percent of GDP. 
of banks to a benchmark socially optimal level. The most striking result here is that when liquidity in the market for external finance is low, for example, in business downturns or as crises become imminent, banks may hoard excessive liquidity.

In the presence of regulation, however, policy interventions to resolve bank failures (bailouts and government-assisted sales) can have nuanced effects on ex-ante bank liquidity. Such policy implications seem pertinent and are worthy of further study, both theoretically, for example, by allowing for formal business-cycle dynamics, and empirically, for example, in the form of specific case studies linking the ex-ante choice of bank liquidity to the regulatory choice of crisis resolution policies.

\section{References}

Acharya, Viral, Heitor Almeida and Murillo Campello (2007), Is Cash Negative Debt? - A Hedging Perspective on Corporate Financial Policies, Journal of Financial Intermediation, 16(4), 515-554.

Acharya, Viral, Sreedhar T. Bharath and Anand Srinivasan (2006), Does Industry-wide Distress Affect Defaulted Firms? - Evidence from Creditor Recoveries, Journal of Financial Economics, 85(3),787-821.

Acharya, Viral and Tanju Yorulmazer (2007), Too Many to Fail - An Analysis of Timeinconsistency in Bank Closure Policies, Journal of Financial Intermediation, 16 (1), $1-31$.

Acharya, Viral and Tanju Yorulmazer (2008), Cash-in-the-Market Pricing and Optimal Resolution of Bank Failures, Review of Financial Studies, 21(6), 2705-2742.

Acharya, Viral, Denis Gromb and Tanju Yorulmazer (2007), Imperfect Competition in the Inter-Bank Market for Liquidity as a Rationale for Central Banking, Working Paper, London Business School.

Acharya, Viral, Hyun Song Shin and Tanju Yorulmazer (2009), A Theory of Slow Moving Capital and Contagion, Working Paper, New York University Stern School of Business.

Allen, Franklin and Elena Carletti (2006) Credit Risk Transfer and Contagion, Journal of Monetary Economics, 53, 89-111. 
Allen, Franklin and Elena Carletti (2008) The Role of Liquidity in Financial Crises, Proceedings of the 2008 Jackson Hole Symposium, Federal Reserve Bank of Kansas City

Allen, Franklin and Douglas Gale (1994), Limited Market Participation and Volatility of Asset Prices, American Economic Review, 84, 933-955.

Allen, Franklin and Douglas Gale (1998), Optimal Financial Crises, Journal of Finance, 53(4), 1245-1284.

Allen, Franklin and Douglas Gale (2004a), Financial Fragility, Liquidity and Asset Prices, Journal of the European Economic Association, 2 (6), 1015-1048.

Allen, Franklin and Douglas Gale (2004b), Financial Intermediaries and Markets, Econometrica, 72, 1023-1061.

Allen, Franklin and Douglas Gale (2005), From Cash-in-the-Market Pricing to Financial Fragility, Journal of the European Economic Association, 3 (2-3), 535-546.

Amihud, Yakov (2002), Illiquidity and Stock Returns: Cross-Section and Time- Series Effects, Journal of Financial Markets, 5, 31-56.

Aspachs, Oriol, Erlend Nier and Muriel Tiesset (2004), Liquidity, Banking Regulation and the Macroeconomy, Working Paper, Bank of England.

Basel Committee on Banking Supervision (2002) Supervisory Guidance on Dealing with Weak Banks, Bank for International Settlements, www.bis.org/publ/bcbs88.htm.

Bekaert, G., C. R. Harvey, and C. Lundblad (2003), Liquidity and Expected Returns: Lessons from Emerging Markets, Working Paper, Columbia University.

Berger, Philip, Eli Ofek and Itzhak Swary (1996) Investor Valuation of the Abandonment Option, Journal of Financial Economics, 42, 257-287.

Bernardo, Antonio E. and Ivo Welch (2004), Liquidity and Financial Market Runs, Quarterly Journal of Economics, 199 (1), 135-158.

Bhattacharya, Sudipto and Douglas Gale (1987), Preference Shocks, Liquidity and Central Bank Policy, in William Barnett and Kenneth Singleton, eds.: New Approaches to Monetary Economics, Cambridge University Press, New York. 
Bolton, Patrick, Tano Santos and Jose Scheinkman (2008), Inside and Outside Liquidity, Working Paper, Columbia University.

Brown, Craig O. and Serdar Dinc (2009), Too Many to Fail? Evidence of Regulatory Forbearance When the Banking Sector is Weak, Review of Financial Studies, forthcoming.

Brunnermeier, Markus and Lasse Heje Pedersen (2005), Predatory Trading, Journal of Finance, Vol. 60, No. 4, 1825-63.

Calomiris, Charles W. (1998) Blueprints for a Global Financial Architecture, Reform Proposals, International Monetary Fund.

Calomiris, Charles W., and Gary Gorton (1991), "The Origins of Banking Panics: Models, Facts, and Bank Regulation," in R. Glenn Hubbard, ed., Financial Markets and Financial Crises, University of Chicago.

Calomiris, Charles and Charles Kahn (1991), The Role of Demandable Debt in Structuring Optimal Banking Arrangements, American Economic Review, 81, 497-513.

Caprio, Gerard and Daniela Klingebiel (1996) Bank Insolvencies: Cross Country Experience, World Bank, Policy Research Working Paper No. 1620.

Caprio, Gerard, Luc Laeven, and Ross Levine (2005) Governance and Bank Valuation, Working Paper, Department of Economics, Brown University.

Cifuentes, Rodrigo, Gianluigi Ferucci and Hyun Song Shin (2005), Liquidity Risk and Contagion, Journal of the European Economic Association, 3 (2-3), 556-566.

Claessens, Stijn, Simeon Djankov and Daniela Klingebiel (1999) Financial Restructuring in East Asia: Halfway There?, World Bank, Financial Sector Discussion Paper No. 3.

Cleveland, van B. Harold and Thomas F. Huertas (1985) Citibank, 1812-1970, Harvard University Press, Cambridge, Massachusetts.

Diamond, Douglas and Philip Dybvig (1983) Bank Runs, Deposit Insurance, and Liquidity, Journal of Political Economy, 91, 401-419.

Diamond, Douglas and Raghuram Rajan (2005), Liquidity Shortages and Banking Crises, Journal of Finance, Vol. LX(2), 615-647. 
Diamond, Douglas and Raghuram Rajan (2009), Fear of Fire Sales and the Credit Freeze, Working Paper, University of Chicago's Booth School of Business.

Donaldson, R.G. (1992), Costly Liquidation, Interbank Trade, Bank Runs and Panics, Journal of Financial Intermediation, 2, 59-85.

Freedman, Paul and Reid Click (2006) Banks that Don't Lend? Unlocking Credit to Spur Growth in Developing Countries, Development Policy Review, 24 (3), 279-302.

Gondat-Larralde, Celine and Erlend Nier (2006) Switching costs in the market for personal current accounts: some evidence for the United Kingdom, Bank of England Working Paper No.292.

Gorton, Gary and Lixin Huang (2004) Liquidity, Efficiency, and Bank Bailouts, American Economic Review, 94(3), 455-483.

Gorton, Gary and George Pennacchi (1995) Banks and Loan Sales: Marketing Non-marketable Assets, Journal of Monetary Economics, 35, 389-411.

Gorton, Gary and Andrew Metrick (2009). "Securitized Banking and the Run on Repo," Working Paper, Yale University.

Hart, Oliver and John Moore (1994) A Theory of Debt Based on the Inalienability of Human Capital, Quarterly Journal of Economics, 109(4), 841-879.

Hoggarth, Glenn, Reis, Ricardo and Victoria Saporta (2002) Costs of Banking System Instability: Some Empirical Evidence, Journal of Banking and Finance, 26 (5), 825-855.

Holmstrom, Bengt and Jean Tirole (1998) Private and Public Supply of Liquidity, Journal of Political Economy, 106(1), 1-40.

Holmstrom, Bengt and Jean Tirole (2001) LAPM - A Liquidity-Based Asset Pricing Model, Journal of Finance, 56(5), 2001.

Honohan, Patrick and Daniela Klingebiel (2000) Controlling Fiscal Costs of Bank Crises, World Bank, Working Paper \#2441.

James, Christopher (1987) Some evidence of the uniqueness of bank loans, Journal of Financial Economics 19, 217-235 
James, Christopher (1991) The Losses Realized in Bank Failures, Journal of Finance, 46(4), $1223-1242$.

Jensen, Michael C., William H. Meckling (1976) Theory of the Firm: Managerial Behavior, Agency Costs and Ownership Structure, Journal of Financial Economics, 3(4), 305-360.

Kim, M, Kliger, D and Vale, B (2003), Estimating switching costs and oligopolistic behavior: the case of banking, Journal of Financial Intermediation, 12(1), 25-56.

Kiser, E. (2002) Household switching behavior at depository institutions: evidence from survey data, Working Paper, Finance and Economics Discussion Series, Federal Reserve Board of Governors.

La Porta, Rafael, Florencio Lopez de Silanes and Andrei Shleifer (1999) Corporate Ownership Around the World, Journal of Finance, 54, 471-517.

Levine, Ross and Sergio Schmukler (2005) Internalization and Stock Market Liquidity, NBER Working Paper 11894.

Morris, Stephen and Hyun Shin (2004), Liquidity Black Holes, Review of Finance, 8, 1-18.

Pulvino, Todd C. (1998) Do Asset Fire Sales Exist: An Empirical Investigation of Commercial Aircraft Sale Transactions, Journal of Finance, 53, 939-978.

Rajan, Raghuram and Luigi Zingales (1998) Financial Dependence and Growth, American Economic Review, 88, 559-586.

Rajan, Raghuram and Luigi Zingales (2003) The Great Reversals: The Politics of Financial Development in the 20th Century, Journal of Financial Economics, 69 (1), 5-50.

Repullo, Rafael (2005) Liquidity, Risk Taking, and the Lender of Last Resort, International Journal of Central Banking, 2, 47-80.

Schnabel, Isabel and Hyun Shin (2004), Liquidity and Contagion: the Crisis of 1763, Journal of the European Economic Association, 2 (6), 929-968.

Shin, Hyun Song (2008), Reflections on Modern Bank Runs: A Case of Northern Rock, Journal of Economic Perspectives, 23(1), 101-119. 
Shleifer, Andrei and Robert W. Vishny (1992), Liquidation Values and Debt Capacity: A Market Equilibrium Approach, Journal of Finance, 47, 1343-1366.

Shleifer, Andrei and Robert W. Vishny (1997), The Limits of Arbitrage, Journal of Finance, $52(1), 35-55$.

Stromberg, Per (2000) Conflicts of Interest and Market Illiquidity in Bankruptcy Auctions:

Theory and Tests, Journal of Finance, 55, 2641-2692.

Williamson, Oliver E. (1988) Corporate Finance and Corporate Governance, Journal of Finance, 43, 567-592.

\section{Appendix}

Technical model assumptions: We make the following parametric assumptions to analyze the model. Because of deposit insurance, we assume $d=1$, which makes the expressions for the following parametric assumptions simpler.

(A1) $b>2$ : In this case, the return from the bank's portfolio, $[l+(1-l) R]$, without the profits from the asset purchase, is decreasing as the liquid asset $l$ in bank's portfolio increases. This creates the trade off between the liquid and the illiquid asset only once benefits from fire-sales are introduced. In other words, the pure portfolio choice problem would lead to liquidity choice of $l=0$.

(A2) $\tau<1 / b$ : This guarantees that the liquidity banks have for asset purchases increases as they hold more liquid asset $l$ in their portfolio, that is, $\frac{\partial L}{\partial l}>0$.

(A3) $\bar{\Delta}<\left(b-\frac{3}{2}\right):$ Note that the maximum value $\bar{\Delta}$ can take, denoted by $\bar{\Delta}_{\text {max }}$, is equal to $(R-d)$. This condition guarantees that $\bar{\Delta}<\bar{\Delta}_{\text {max }}$.

(A4) $B \leqslant\left(\frac{\bar{\Delta}^{2}}{b-1}\right)$ : This condition guarantees that banks cannot generate a higher proportion of their future profits in the capital market when they invest in the bad project. In particular, when bank owners are left with a share of profits less than $\bar{\theta}$, they shirk, which results in a lower return from these investments. However, in that case, they can generate a higher proportion of their future profits in the capital market, that is, they can generate up to $(R-\bar{\Delta}-d)$. Banks can generate higher funds from the capital market when they choose 
the good project if

$$
(1-\bar{\theta})(R-d) \geqslant R-\bar{\Delta}-d
$$

which gives us $\bar{\theta} \leqslant \frac{\bar{\Delta}}{(R-d)}$. Thus, we have $\bar{\theta}=\frac{B}{\bar{\Delta}} \leqslant \frac{\bar{\Delta}}{(R-d)}$. In that case, it is optimal to leave a minimum share of $\bar{\theta}$ of future profits to bank managers, both for higher output as well as better liquidity generation through the capital market. This condition simplifies to $B \leqslant\left(\frac{\bar{\Delta}^{2}}{b-1}\right)$.

Proof of Proposition 2: We have $R(l)=\left[b-\frac{(1-l)}{2}\right]$ and $\frac{d R}{d l}=\frac{1}{2}$. Plugging these expressions into the FOC in (10), we get:

$$
E(\alpha)[1-b+(1-l)]+E(\phi)[1+\tau[-b+(1-l)]]=0,
$$

where $\phi$ is the expected benefit per unit of failed banks' assets from asset purchase. From here, we can find banks' choice of liquidity $\widehat{l}$ that satisfies the FOC as:

$$
\widehat{l}=1-b+\frac{E(\alpha)+E(\phi)}{E(\alpha)+\tau E(\phi)},
$$

which is given in Proposition 2.

We have the following:

$$
\phi=\left\{\begin{array}{lll}
0 & \text { for } & k \leqslant \underline{k} \\
\alpha\left(\frac{(1-l)(1-\alpha) \bar{p}}{\alpha L}-1\right) & \text { for } & k>\underline{k}
\end{array} .\right.
$$

Note that $\underline{k}$ is continuos in $l$. Thus, $E(\phi)$ is continuos in $l$. Hence, $\widehat{l}$ is continuos in $l$. Since, $\widehat{l}$ is a continuos function from the compact, convex set $[0,1]$ into itself, by Brouwer's fixed point theorem, a fixed point of the mapping in equation (34) exists. Next, we show that the fixed point is unique.

Note that as $l$ increases, the aggregate liquidity increases, and the region over which the price of the failed banks' assets fall below their fundamental value shrinks, that is, $\frac{\partial k}{\partial l}>0$. Hence, we have $\frac{\partial E(\phi)}{\partial l}<0$. Note that, we have $\operatorname{sign}\left(\frac{\partial \hat{l}}{\partial E(\phi)}\right)=\operatorname{sign}[(1-\tau) E(\alpha)]$, where $(1-\tau) E(\alpha)>0$. Hence, as the expected private benefit from holding the liquid asset decreases, banks hold less liquid asset in their portfolio. Thus, we have $\frac{\partial \widehat{l}}{\partial l}<0$. As a result, the fixed point is unique. 
Next, we show that $l^{*} \leqslant l_{\max }$. Note that by investing everything in the safe asset at $t=0$, banks can avoid failure. First, we look at the case where banks take risks, that is, they choose $l<1$. Then, we show that banks in equilibrium choose $l<1$.

Consider first the case when $(1-l) R \geqslant d$. In this case, a proportion $\tau$ of the remaining return from the risky asset, that is, $\tau[(1-l) R-d]$ can be pledged in the capital market. Thus, from equation (4), we have

$$
\frac{\partial L}{\partial l}=1-\tau R+\tau(1-l)\left(\frac{d R}{d l}\right)=1+\tau(-b+1-l) .
$$

Hence, for $\tau<\left(\frac{1}{b-1+l}\right)$, we have $\frac{\partial L}{\partial l} \geqslant 0$ and liquidity available for asset purchase increases as banks hold more of the liquid asset in their portfolio. A sufficient condition for this to hold is $\tau<1 / b$, which holds by our assumption (A2).

For the other case, $l>l_{\max }$ and the return from the risky asset is not enough to pay old depositors. Hence, some of the liquid asset $l$ has to be used to pay old depositors, and

$$
L=l+(1-l) R-d<l
$$

Thus, for $b>2$ (A1), $\frac{\partial L}{\partial l}<0$ and the liquid asset available for asset purchase decreases as banks hold more of the liquid asset. Furthermore, without the asset purchase, the expected return on bank's portfolio $E\left[\alpha\left(l+(1-l)\left(b-\frac{1-l}{2}\right)\right)\right]$, is decreasing in $l$ for $b>2$. Hence, for $b>2$, banks never hold a level of liquidity $l$ greater than $l_{\max }$ in equilibrium.

When banks invest everything in the safe asset their expected profit is 0 as they need to pay the entire amount back to the depositors. However, due to limited liability, banks' expected profit is positive when they invest a positive amount in the risky asset. Hence, in equilibrium, banks do not invest everything in the safe asset. $\diamond$

Proof of Proposition 3: First, we prove part (i). Note that if $\widehat{l}$ given in equation (12) increases, the privately optimal level of liquidity $l^{*}$ increases. We have

$$
\begin{aligned}
\operatorname{sign}\left(\frac{\partial \hat{l}}{\partial \tau}\right) & =\operatorname{sign}\left[\left(\frac{\partial E(\phi)}{\partial \tau}\right)[E(\alpha)+\tau E(\phi)]-[E(\alpha)+E(\phi)]\left(E(\phi)+\tau\left(\frac{\partial E(\phi)}{\partial \tau}\right)\right)\right] \\
& =\operatorname{sign}\left[\left(\frac{\partial E(\phi)}{\partial \tau}\right)[(1-\tau) E(\alpha)]-E(\phi)[E(\alpha)+E(\phi)]\right] .
\end{aligned}
$$

We have $\frac{\partial E(\phi)}{\partial \tau}<0$, since $\frac{\partial E(\phi)}{\partial p^{*}}<0$ and $\frac{\partial p^{*}}{\partial \tau}>0$. Hence, we have $\frac{\partial \hat{l}}{\partial \tau}<0$, that is, the privately optimal level of liquidity $l^{*}$ decreases as $\tau$ increases. 
Next, we prove part (ii). Note that $\phi$ is (weakly) increasing in $k$, therefore, is (weakly) decreasing in $\alpha$. Hence, if $g$ FOSD $f$, we have $E_{g}(\phi)<E_{f}(\phi)$. We have $\frac{\partial \hat{l}}{\partial E(\phi)}>0$. Hence, if $g$ FOSD $f$, then we have $l_{g}^{*}<l_{f}^{*}$. $\diamond$

Proof of Proposition 5: From the expressions for these two values of liquidity, we obtain

$$
\begin{aligned}
\widehat{l}-\widehat{\vec{l}} & =\frac{E(\alpha)+E(\phi)}{E(\alpha)+\tau E(\phi)}-\frac{1-r(1-E(\alpha))}{E(\alpha)} \\
& =\frac{E(\phi)[E(\alpha)-\tau[1-r(1-E(\alpha))]]-E(\alpha)(1-r)[1-E(\alpha)]}{E(\alpha)[E(\alpha)+\tau E(\phi)]} .
\end{aligned}
$$

Note that a sufficient condition for the socially optimal level of liquidity to be higher that the privately optimal level of liquidity is $E(\alpha)<\frac{\tau(1-r)}{1-\tau r}$. Hence, we analyze the case where $E(\alpha) \geqslant \frac{\tau(1-r)}{1-\tau r}$. As $E(\alpha)$ converges to 1, we have the privately optimal level of liquidity to be higher than the socially optimal level. Next, note that $\widehat{l}=\widehat{\hat{l}}$ when

$$
E(\phi)[E(\alpha)-\tau[1-r(1-E(\alpha))]]=E(\alpha)(1-r)[1-E(\alpha)] .
$$

Since the left hand side is decreasing in $\tau$, but the right hand side is not affected by $\tau$, this equation implicitly defines a unique critical $\tau^{*}(E(\alpha))$ such that $\widehat{l}<\widehat{\hat{l}}$ if and only if $\tau>\tau^{*}(E(\alpha))$.

Using the implicit function theorem, we get:

$$
\begin{aligned}
& E(\phi)\left[\frac{d \tau^{*}}{d E(\alpha)}\right][1-r(1-E(\alpha))] \\
= & E(\phi)(1-\tau r)+[E(\alpha)-\tau[1-r(1-E(\alpha))]]\left[\frac{d E(\phi)}{d E(\alpha)}\right]-(1-r)[1-2 E(\alpha)] .
\end{aligned}
$$

Note that $\frac{d E(\phi)}{d E(\alpha)}<0$ so that we obtain

$$
\frac{d \tau^{*}}{d E(\alpha)}<0 \text { for } E(\alpha)<\frac{1}{2}-\frac{E(\phi)(1-\tau r)}{2(1-r)} .
$$

See Figure 7 for an illustration. $\diamond$ 


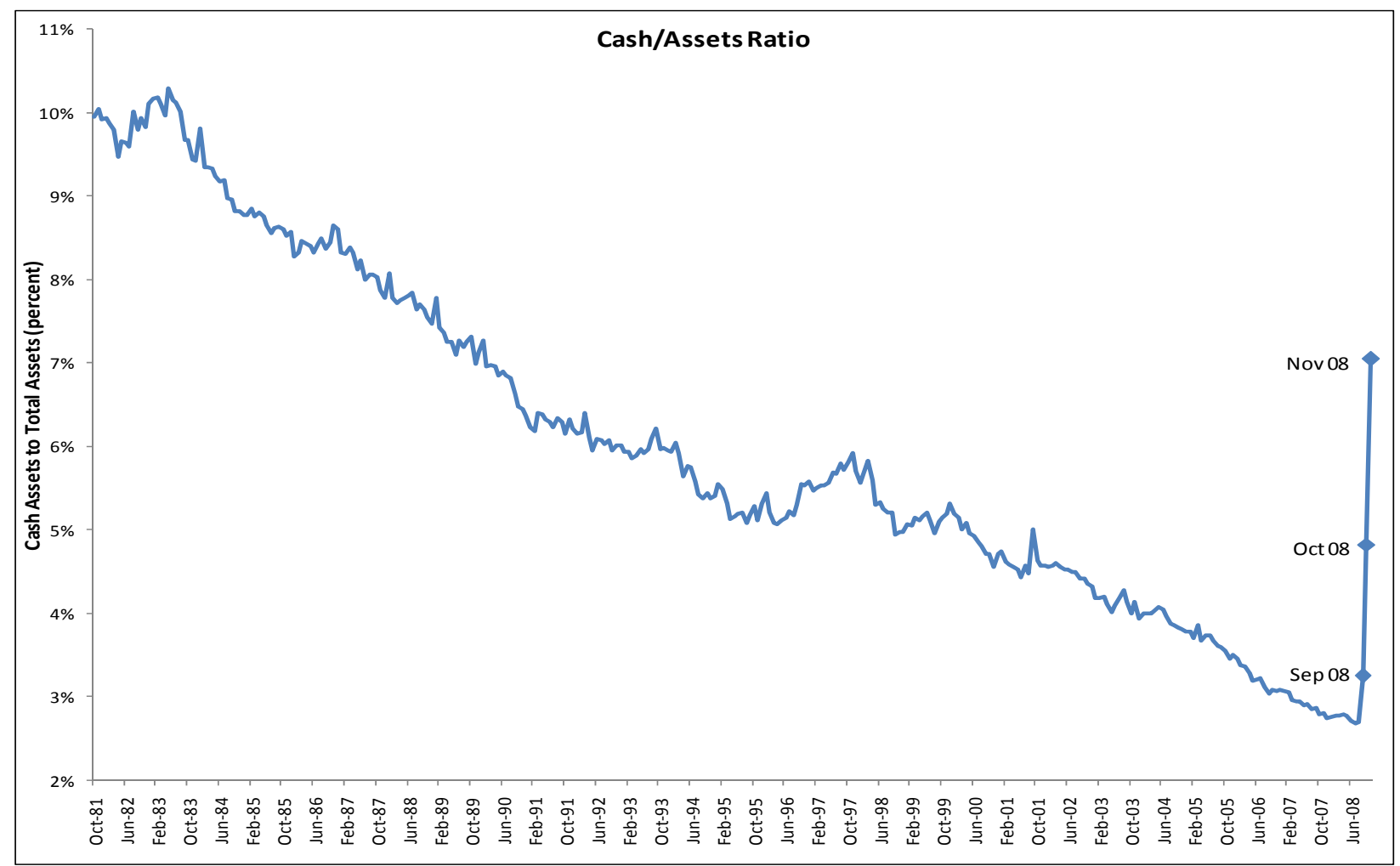

Figure 1: Monthly Cash Holdings of U.S. Commercial Banks (Source: Federal Reserve H8)

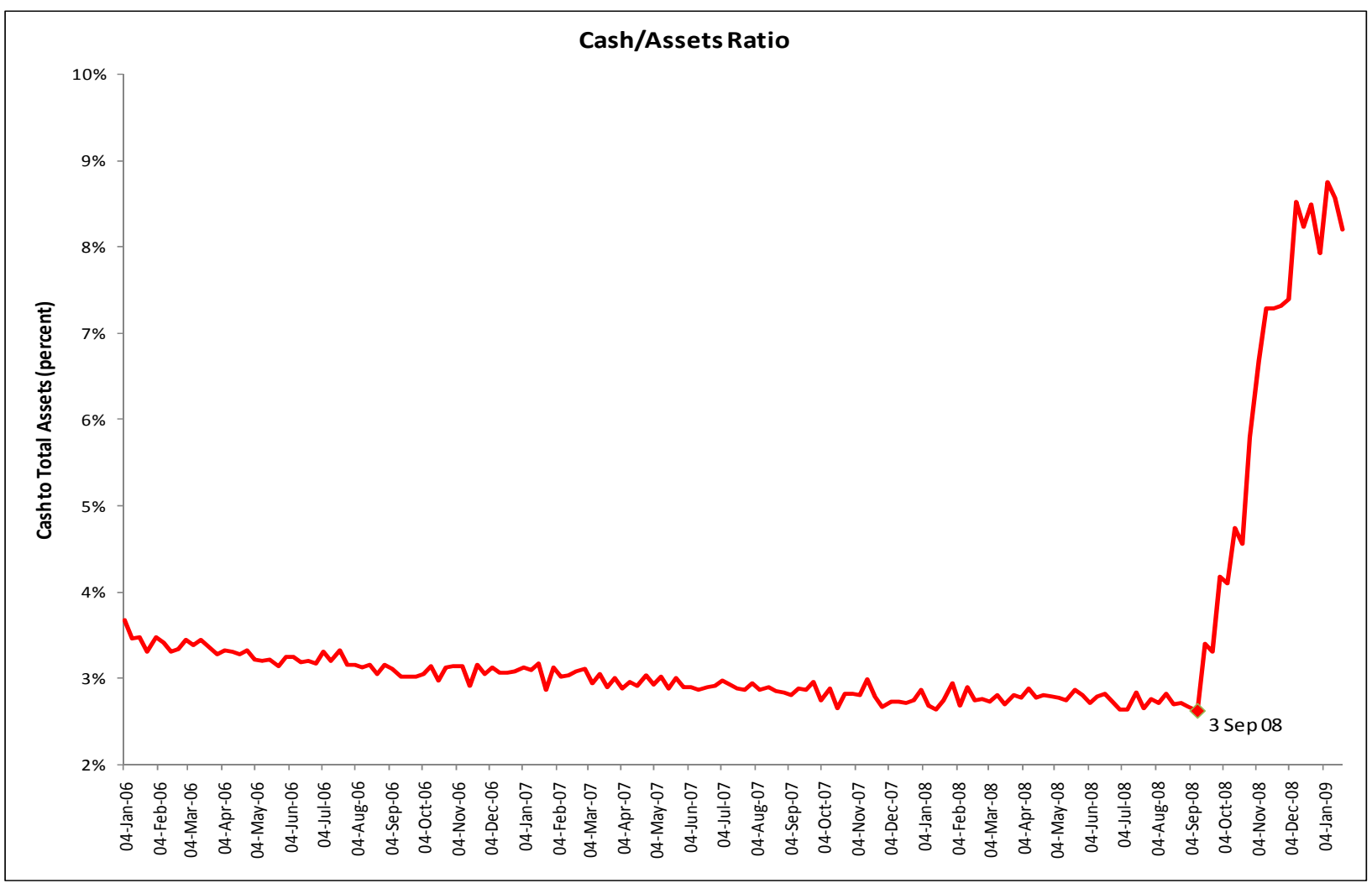

Figure 2: Weekly Cash Holding of U.S. Commercial Banks (Source: Federal Reserve H8) 


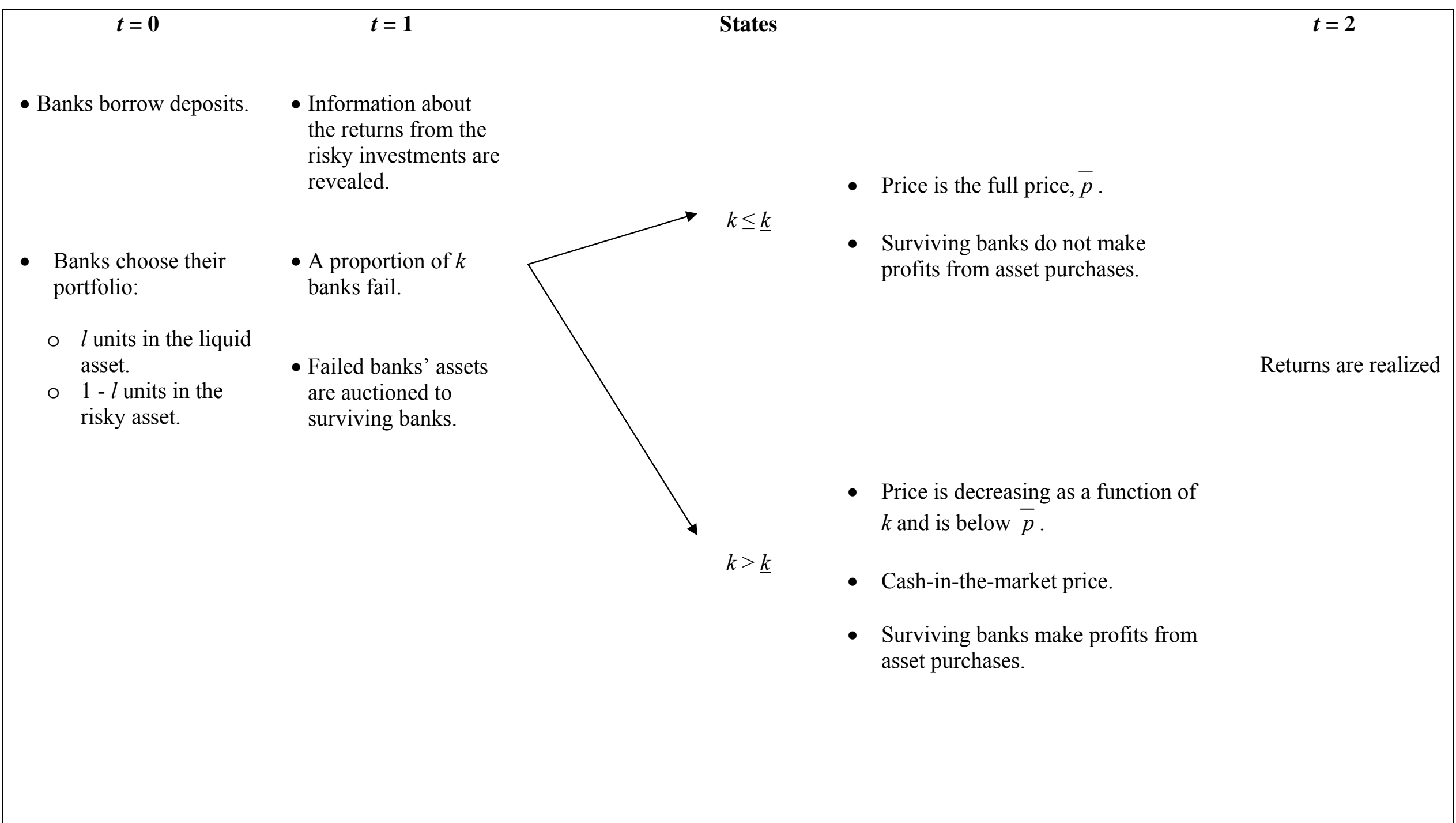

Figure 3: Timeline of the benchmark model. 


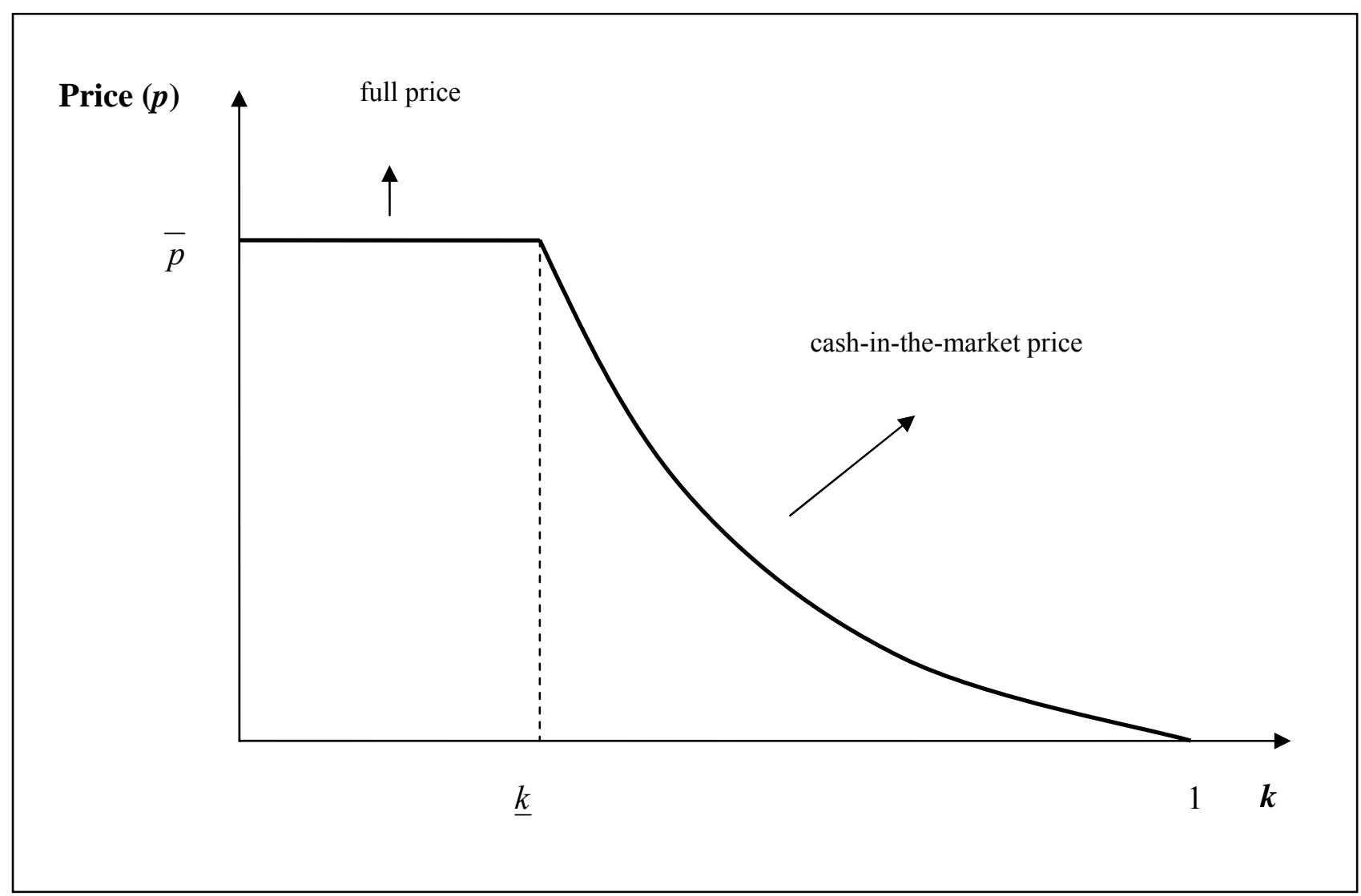

Figure 4: Price in Proposition 1.

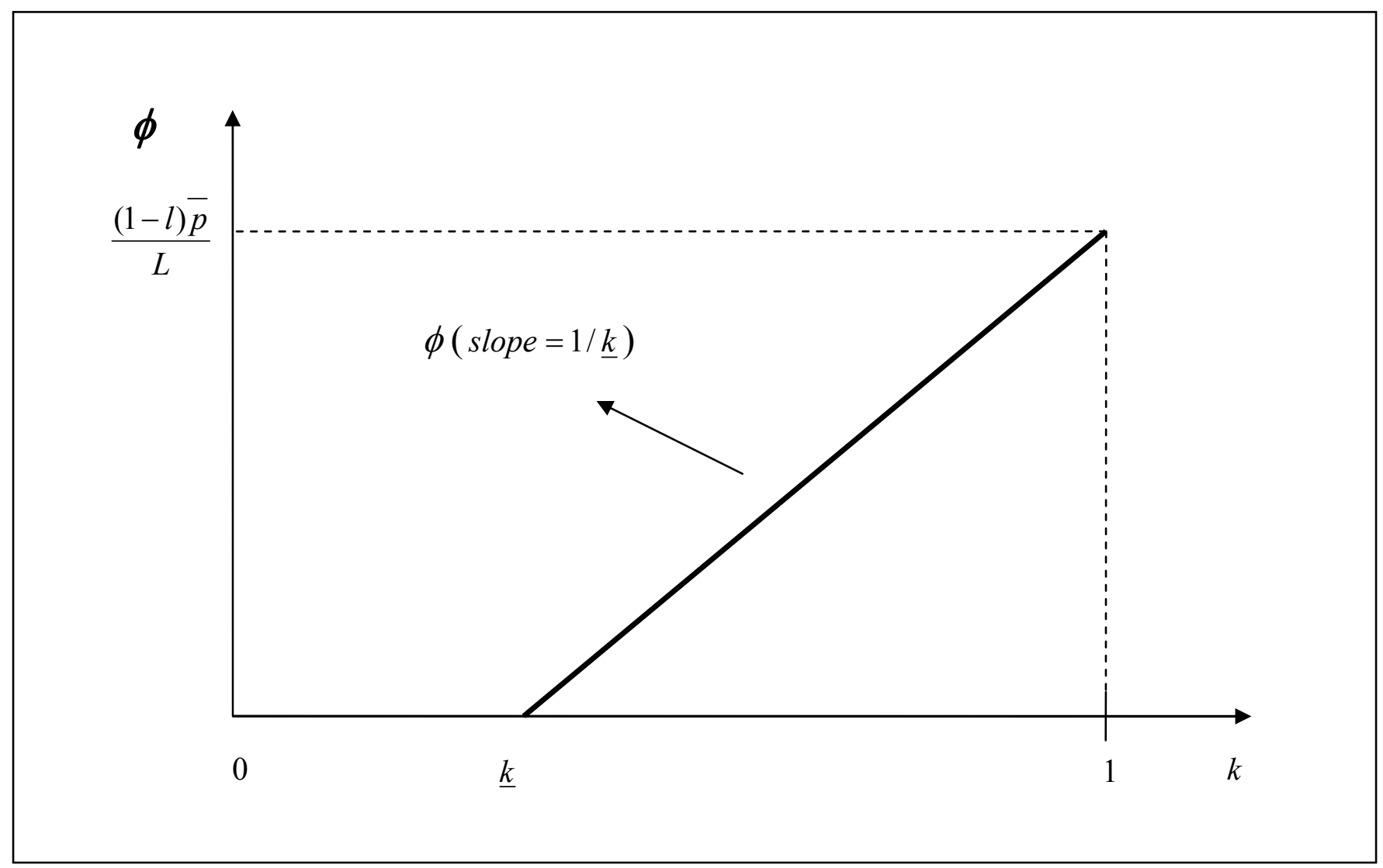

Figure 5: Marginal private ( $\phi$ ) benefit from the liquid asset (no outsiders). 


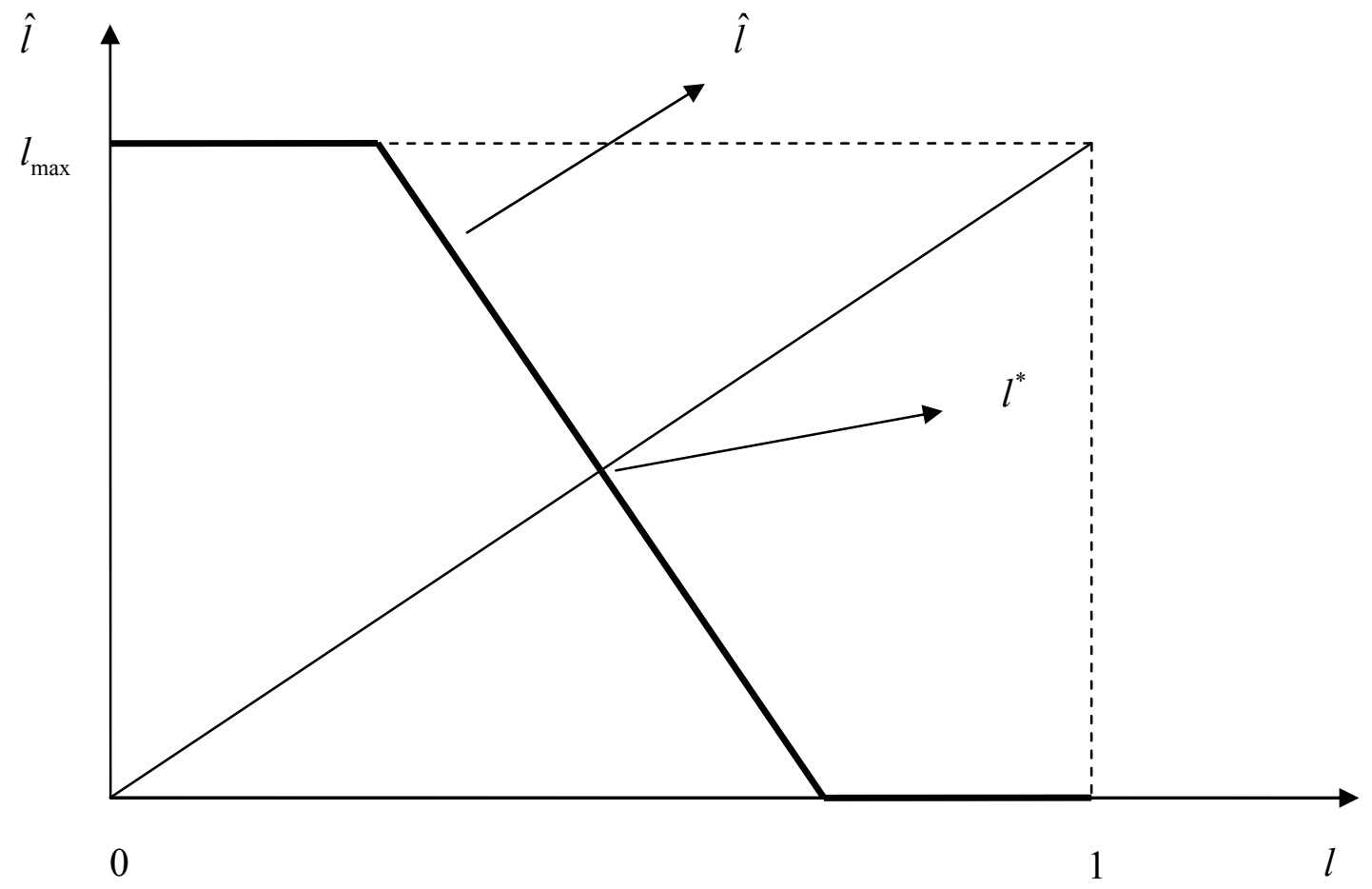

Figure 6: Privately optimal choice of liquidity and the equilibrium (Proposition 2).

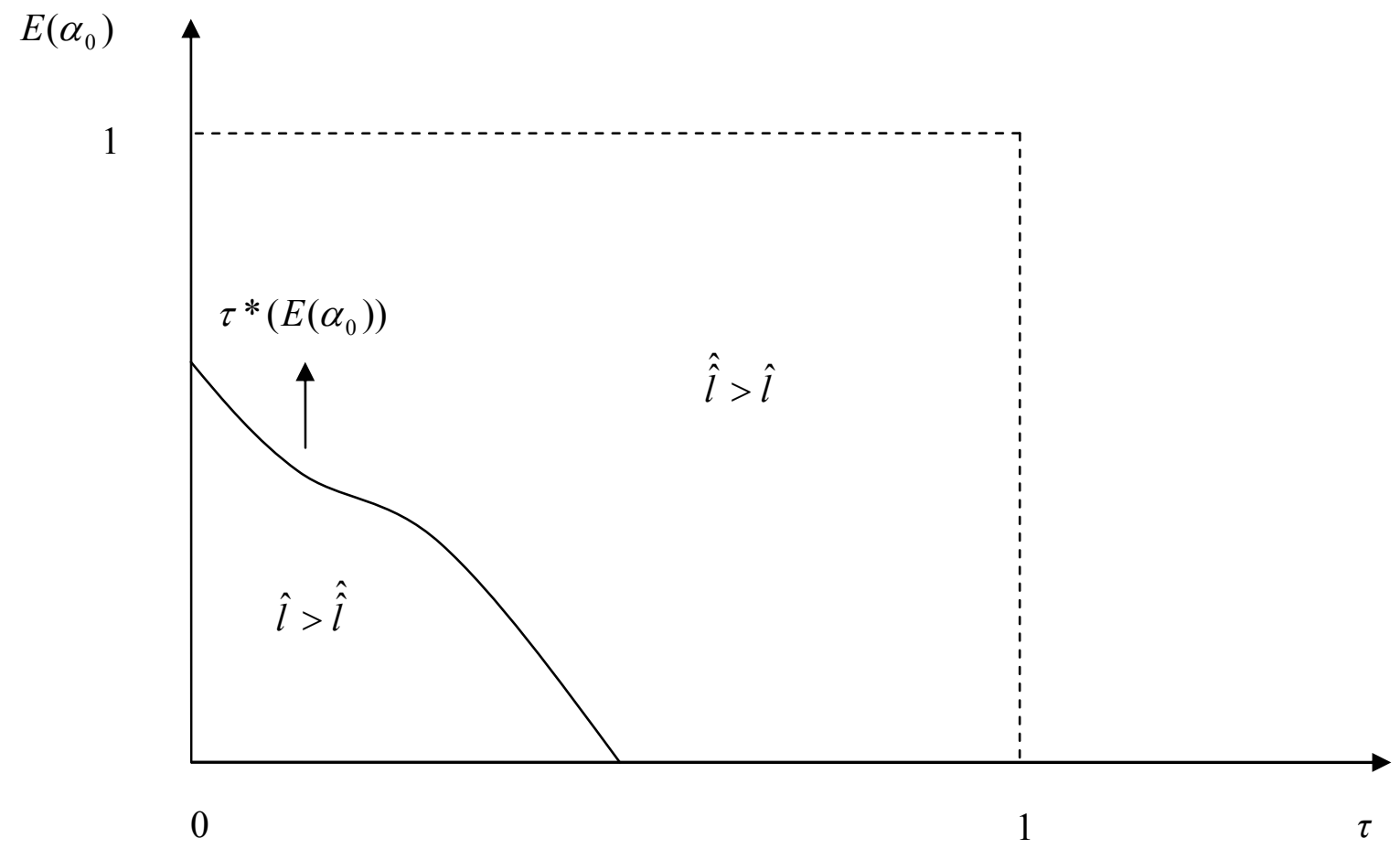

Figure 7: Comparison of privately and socially optimal levels of liquidity. 
Figure 8: Liquidity ratio and its Fitted value vs Accounting standards

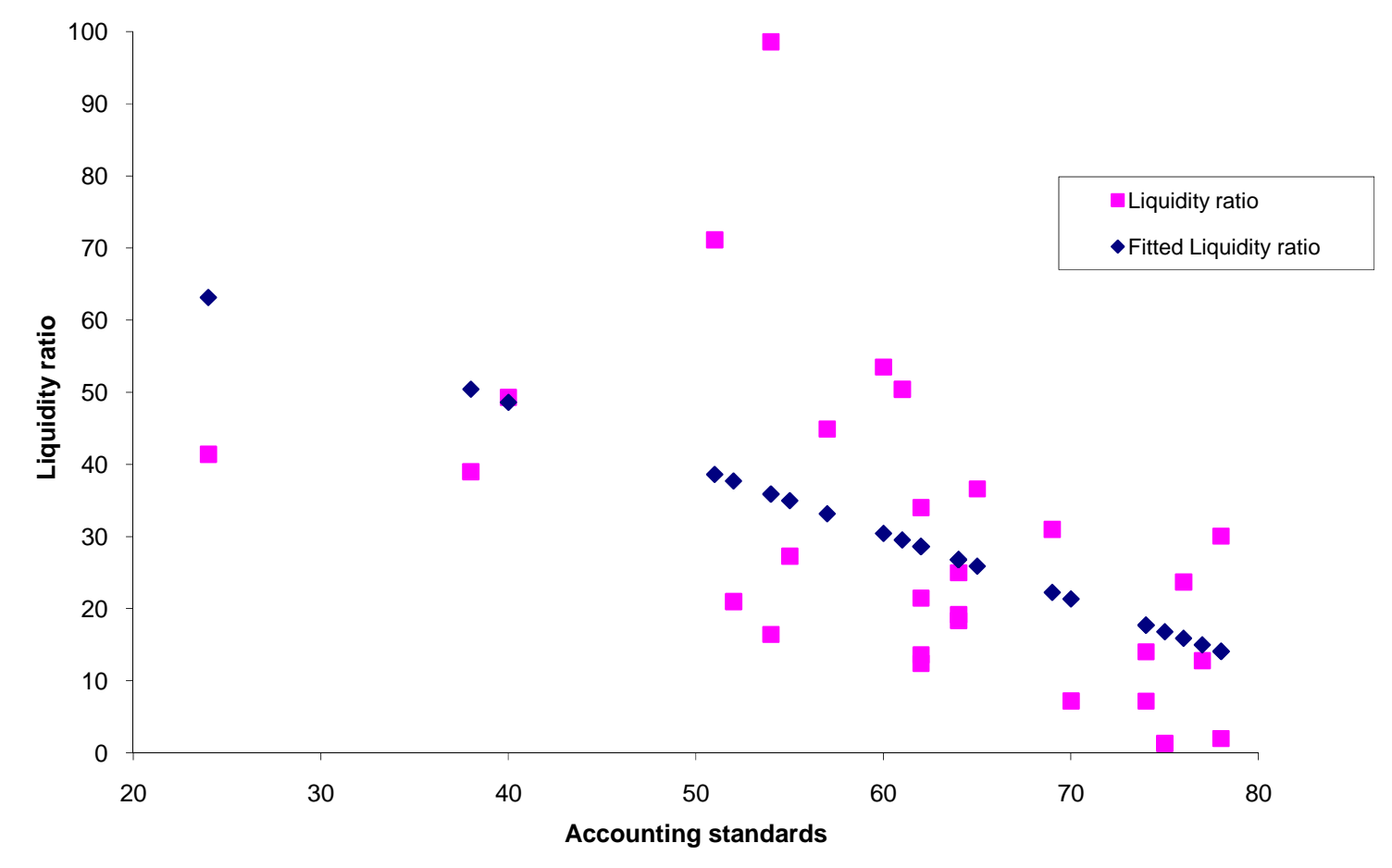

Figure 9: Liquidity ratio and its Fitted value vs Total Cap to GDP ratio

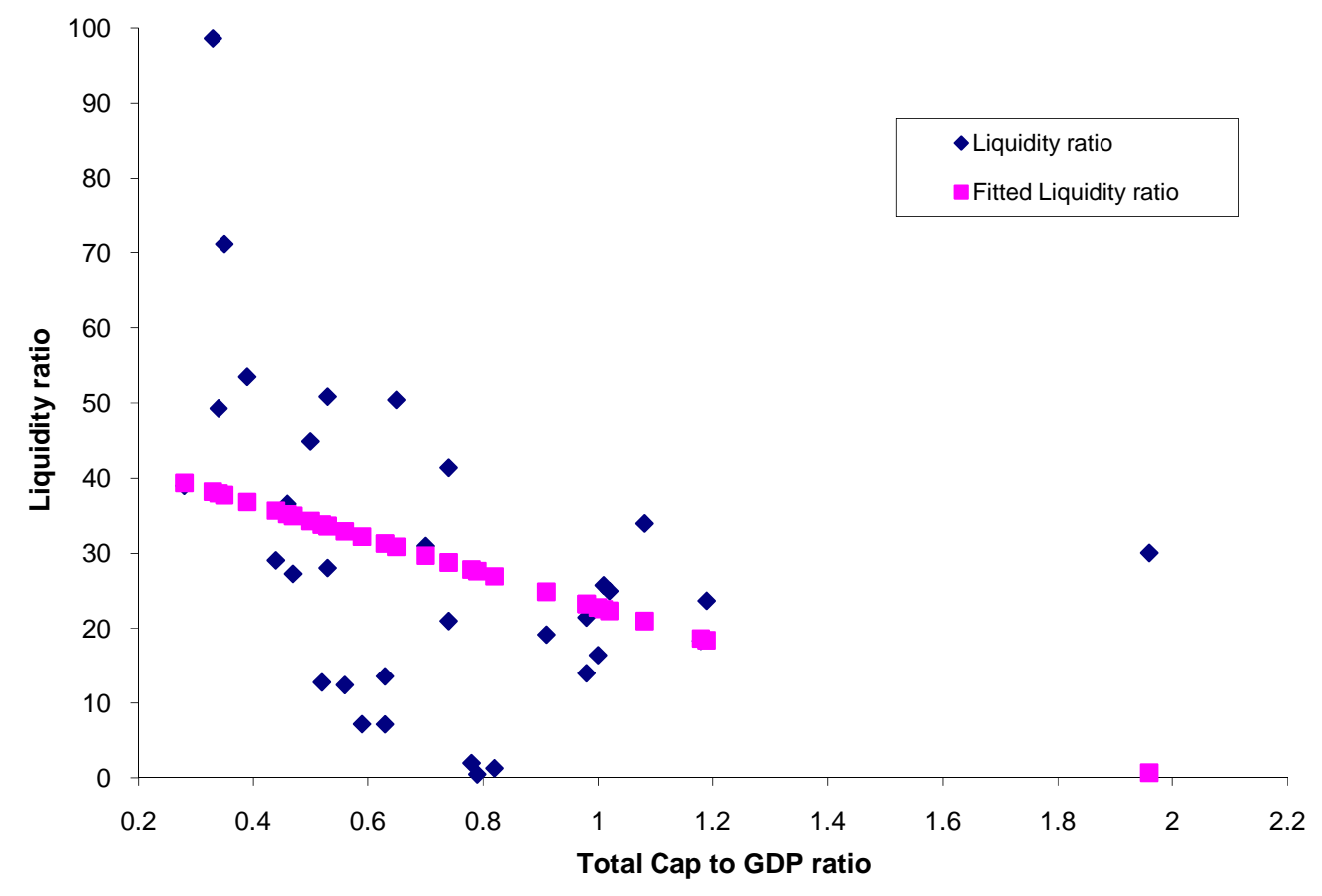


Figure 10: Liquidity ratio vs Stock market illiquidity (\% Zero return days)
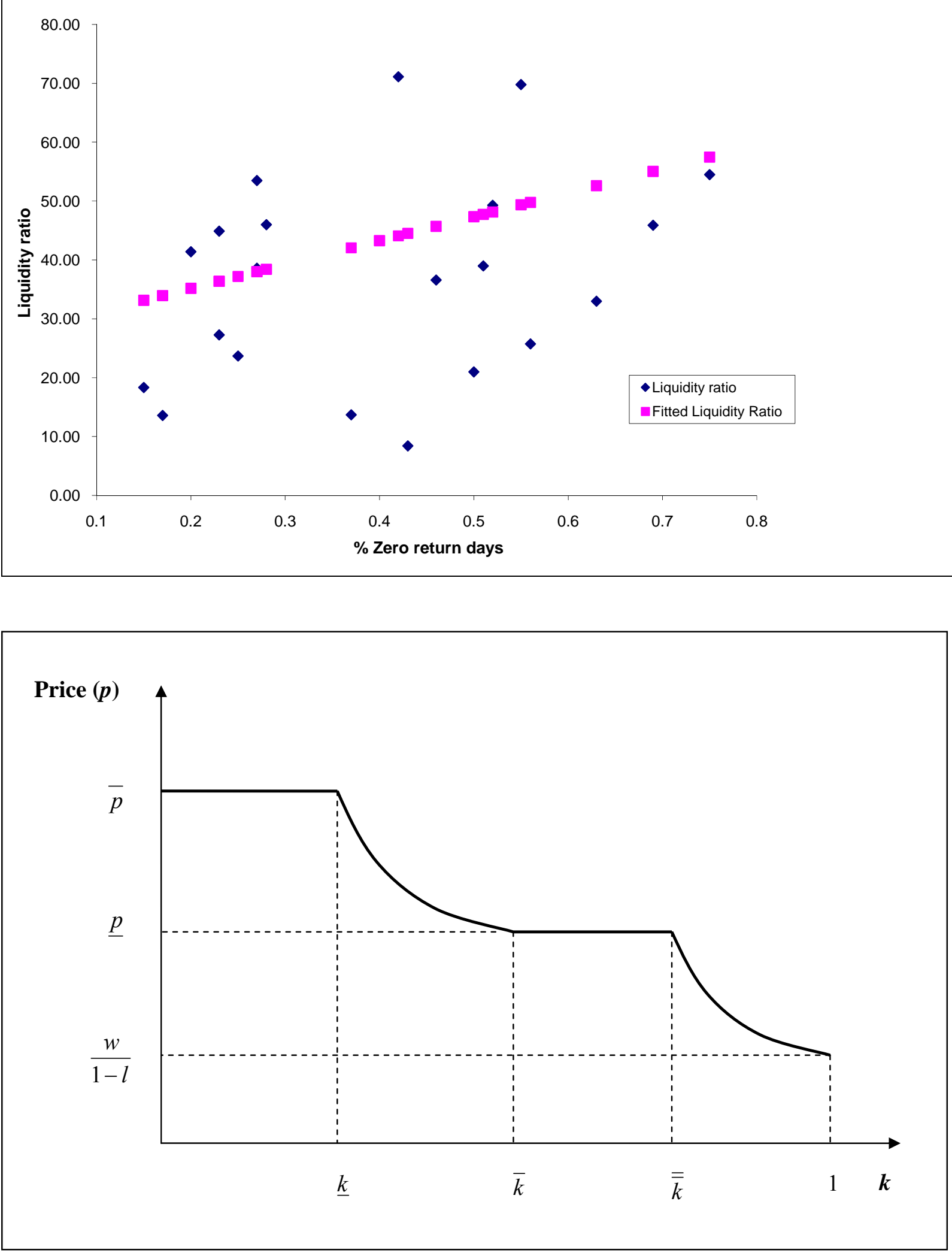

Figure 11: Price in Proposition 6. 